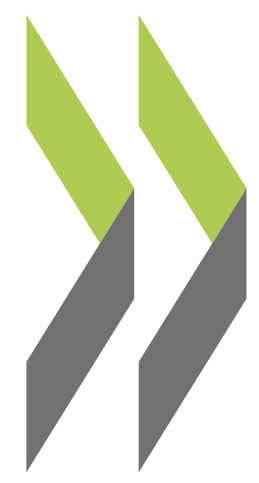

OECD Economics Department Working Papers No. 1650

Regional development in Lithuania: A tale of two economies

Hansjörg Blöchliger, Roland Tusz 


\section{ECONOMICS DEPARTMENT}

\section{REGIONAL DEVELOPMENT IN LITHUANIA: A TALE OF TWO ECONOMIES}

\section{ECONOMICS DEPARTMENT WORKING PAPERS No. 1650}

By Hansjörg Blöchliger and Roland Tusz

OECD Working Papers should not be reported as representing the official views of the OECD or of its member countries. The opinions expressed and arguments employed are those of the author(s).

Authorised for publication by Alvaro Pereira, Director, Country Studies Branch, Economics Department.

All Economics Department Working Papers are available at www.oecd.org/eco/workingpapers

JT03469865 
OECD Working Papers should not be reported as representing the official views of the OECD or of its member countries. The opinions expressed and arguments employed are those of the author(s).

Working Papers describe preliminary results or research in progress by the author(s) and are published to stimulate discussion on a broad range of issues on which the OECD works.

Comments on Working Papers are welcomed, and may be sent to the Economics Department, OECD, 2 rue AndréPascal, 75775 Paris Cedex 16, France, or by e-mail to eco.contact@oecd.org.

All Economics Department Working Papers are available at www.oecd.org/eco/workingpapers.

This document and any map included herein are without prejudice to the status of or sovereignty over any territory, to the delimitation of international frontiers and boundaries and to the name of any territory, city or area.

The statistical data for Israel are supplied by and under the responsibility of the relevant Israeli authorities. The use of such data by the OECD is without prejudice to the status of the Golan Heights, East Jerusalem and Israeli settlements in the West Bank under the terms of international law.

Note by Turkey

The information in this document with reference to "Cyprus" relates to the southern part of the Island. There is no single authority representing both Turkish and Greek Cypriot people on the Island. Turkey recognises the Turkish Republic of Northern Cyprus (TRNC). Until a lasting and equitable solution is found within the context of the United Nations, Turkey shall preserve its position concerning the "Cyprus issue".

Note by all the European Union Member States of the OECD and the European Union

The Republic of Cyprus is recognised by all members of the United Nations with the exception of Turkey. The information in this document relates to the area under the effective control of the Government of the Republic of Cyprus.

\section{(C) OECD (2020)}

You can copy, download or print OECD content for your own use, and you can include excerpts from OECD publications, databases and multimedia products in your own documents, presentations, blogs, websites and teaching materials, provided that suitable acknowledgment of OECD as source and copyright owner is given. Requests for commercial use and translation rights should be submitted to PubRights@oecd.org. 


\section{Abstract/Resume \\ Regional development in Lithuania: a tale of two economies}

Regional differences in GDP per capita, productivity, employment and poverty in Lithuania are among the largest in the OECD, and they have increased over the last decade. The country still recovers from the legacy of the Soviet planning system which aimed at balanced geographical distribution of industrial activity and left many unviable firms and jobs particularly in rural areas. Unemployment is high in many regions, while mobility of excess labour towards economically stronger areas remains insufficient. Some regions feature "surplus infrastructure", while others lack investment. This paper looks at potential reasons for persisting disparities and assesses recent policy initiatives to reduce them. Stark gaps in education outcomes between rural and urban areas should be addressed, mainly by reorganising the municipal school network and by fostering firm-based learning, i.e. apprenticeships. The digital infrastructure is weak in rural regions and should be strengthened to allow access to high-quality jobs in all parts of the country, including through teleworking. Housing supply in economically strong areas should be increased, while urban sprawl should be avoided. Finally, municipal governments should be given more fiscal power, while the planned functional regions should help foster inter-municipal coordination.

This Working Paper relates to the 2020 OECD Economic Survey of Lithuania http://www.oecd.org/economy/lithuania-economic-snapshot/.

JEL classification: D24, H70, I24, J24, J61, J65, O31

Key words: Lithuania, regional development, regional productivity, labour mobility, regional disparities, education, regional infrastructure, fiscal decentralisation.

This working paper relates to the 2020 OECD Economic Survey of Lithuania.

\section{Le développement régional en Lituanie: I'histoire d'un pays avec une économie à deux vitesses}

Les différences régionales de PIB par habitant, de productivité, d'emploi et de pauvreté en Lituanie sont parmi les plus importantes de l'OCDE, et elles se sont accrues au cours de la dernière décennie. Le pays se remet encore de l'héritage du système de planification soviétique qui visait à équilibrer la répartition géographique de l'activité industrielle et laissait de nombreuses entreprises et emplois non viables, en particulier dans les zones rurales. Le chômage est élevé dans de nombreuses régions, tandis que la mobilité de la main-d'œuvre vers des zones économiquement plus fortes reste insuffisante. Certaines régions disposent d'une " infrastructure excédentaire », tandis que d'autres manquent d'investissements. Cet article examine les raisons potentielles des disparités persistantes et évalue les initiatives politiques récentes pour les réduire. II convient de combler les écarts flagrants dans les résultats de l'éducation entre les zones rurales et urbaines, principalement en réorganisant le réseau scolaire municipal et en favorisant l'apprentissage en entreprise. L'infrastructure numérique est faible dans les régions rurales et devrait être renforcée pour permettre l'accès à des emplois de qualité dans toutes les régions du pays. L'offre de logements dans les zones économiquement fortes devrait être augmentée, tandis que l'étalement urbain devrait être évité. Enfin, les administrations municipales devraient avoir plus de pouvoir budgétaire, tandis que les régions fonctionnelles prévues devraient contribuer à favoriser la coordination intercommunale.

Ce document de travail est lié à l'Étude économique de l'OCDE 2020 consacrée à la Lituanie http://www.oecd.org/fr/economie/lituanie-en-un-coup-d-oeil/

JEL classification: D24, H70, I24, J24, J61, J65, O31

Mots clés: Lituanie, développement régional, productivité régionale, mobilité de la main-d'œuvre, disparités régionales, éducation, infrastructure régionale, décentralisation fiscale.

Ce Document de travail se rapporte à l'Étude économique de l'OCDE de la Lituanie 2020. 


\section{Table of contents}

\section{Regional Development in Lithuania: a Tale of Two Economies}

Regional disparities are high

The state and evolution of disparities

Policies to foster regional convergence $\quad 9$

Fostering skills across the country 9

The primary and secondary education system lacks scale 10

Vocational education and training should better match local labour market needs 13

Universities should specialise more $\quad 15$

The national minimum wage particularly affects regions with many low-skilled workers $\quad 16$

Investing in sustainable infrastructure $\quad 17$

Transport should be improved and become more sustainable $\quad 17$

Digital infrastructure should be improved in rural areas $\quad 20$

Scaling up housing, while reducing urban sprawl $\quad 21$

High ownership rate is likely to reduce labour mobility $\quad 22$

Fostering sustainable urban housing supply could facilitate mobility 24

$\begin{array}{ll}\text { Improving multi-level governance } & 26\end{array}$

Local investment is low and declining $\quad 27$

$\begin{array}{ll}\text { The planned functional regions will improve investment quality } & 29\end{array}$

References $\quad 30$

\section{Tables}

Table 1. Recommendations to foster regional convergence

\section{Figures}

Figure 1. Regional disparities are large, reflecting differences in productivity $\quad 7$

$\begin{array}{lr}\text { Figure 2. Disparities are growing } & 8\end{array}$

Figure 3. Agglomeration economies are at work $\quad 8$

Figure 4. Demand for jobs is higher in more productive regions and for qualified professionals 10

Figure 5. In Lithuania, urban-rural gaps in educational achievements are large 10

Figure 6. Smaller schools are associated with weaker outcomes and higher cost everywhere 11

Figure 7. Educational outcomes in small schools are weaker, while cost is higher 12

Figure 8. Vocational education and training, including apprenticeships, is weak 14

Figure 9. Firms contribute little to university funding in Lithuania 16

Figure 10. The minimum wage has a strong bite in less productive regions $\quad 17$

$\begin{array}{lr}\text { Figure 11. Transport infrastructure needs improvement } & 18\end{array}$

Figure 12. The digital divide between regions is stark $\quad 20$

Figure 13. House prices are low in Lithuania but vary across regions $\quad 22$

Figure 14. High home ownership rates could create a barrier to labour mobility 22

Figure 15. Many apartments need upgrading 23 
Figure 16. Housing supply seems not to follow demand 25

Figure 17. Urban sprawl is increasing, pushing up infrastructure cost $\quad 26$

$\begin{array}{lr}\text { Figure 18. Lithuania is highly centralised } & 27\end{array}$

$\begin{array}{lr}\text { Figure 19. Local investment is low and declining } & 28\end{array}$

\section{Boxes}

Box 1. Are small schools responsible for low education outcomes? An empirical test 11

Box 2. Implementing firm-based learning successfully 15

Box 3. Modernising local and regional public passenger transport $\quad 19$

Box 4. How to bridge the digital divide between urban and rural regions? 21

Box 5. The Slovak Republic's State Housing Development Fund 24

Box 6. Metropolitan governance: current approaches in OECD countries 29 


\title{
Regional Development in Lithuania: a Tale of Two Economies
}

\author{
By Hansjörg Blöchliger and Roland Tusz ${ }^{1}$
}

\section{Regional disparities are high}

\section{The state and evolution of disparities}

Lithuania is a tale of two economies. The capital area and other large conurbations boast GDP per capita, household income and productivity levels close to or above OECD averages. Yet a large part of the peripheral countryside and most small- and medium sized towns are lagging behind, with incomes hardly progressing, unemployment high and emigration abroad often the only way to escape poverty. Overall, Lithuania is among the OECD countries with the highest regional disparities, although on an international scale large regional differences tend to go together with more rapid growth (Figure $1 \mathrm{~A}$ ). As in most countries, productivity gaps account for a large share of the differences in Lithuanian regional GDPs, while employment and participation also contribute to regional disparities (Figure $1 \mathrm{~B}$ ). In particular, older and poor people concentrate in the more rural and remote regions.

\footnotetext{
1 The authors are members of the OECD Economics Department. They would like to thank Ana Moreno Monroy, Enrique Garcilazo and Lisa Michelle Marshalian (CFE), Luca Boeskens and Thomas Radinger (EDU), Vivian Koutsogeorgopoulou, Alvaro Pereira, Emily Sinnott and Piritta Sorsa (ECO) as well as the participants in the Economic Development and Review Committee for useful comments and suggestions. Particular thanks go to Karimatou Diallo and Carolina Gonzales for excellent editorial assistance.
} 


\section{Figure 1. Regional disparities are large, reflecting differences in productivity}

\section{A. Per capita disparities and growth}

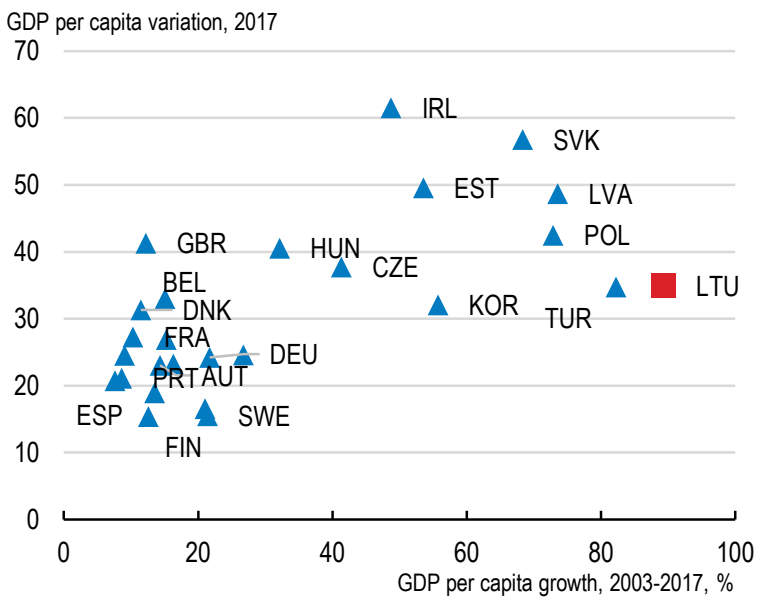

B. Regional disparities decomposition

$\square$ Labour productivity $\quad$ Employment rate a Participation

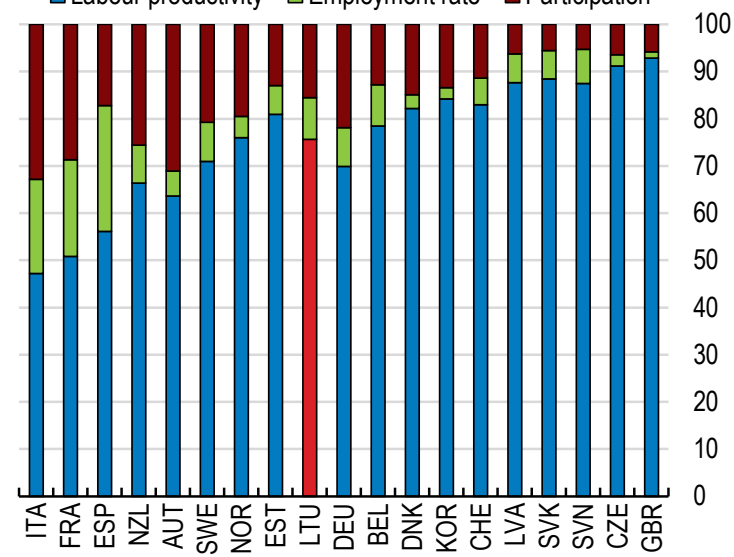

Note: Panel A: the vertical axis refers to the coefficient of variation for regional GDP per capita. Panel B: the variation of regional GDP per capita is decomposed into the contributions of labour productivity (GDP per worker), labour utilisation (share of employed in active working population) and the activity rate (share of active working population in total population). Since an additive aggregation as shown in the figure does not take into account the covariance across components, the variations in each component do not add up to the exact variation in GDP per capita.

Source: OECD Regional database.

StatLink त्ता Th https://doi.org/10.1787/888934185764

The main reason for high and, since 2011, rising regional disparities is a combination of low economic growth and job creation in peripheral areas and insufficient labour mobility, in particular of low-skilled workers, towards economically stronger regions. The gains of Lithuania's globalising economy have concentrated in a few regions that have a qualified workforce and are well integrated in global value chains (Rusticelli and al, 2018 $\left.{ }_{[1]}\right)$. As many countries, Lithuania is converging towards the OECD average, while its individual parts are diverging (Bartolini, Stossberg and Blöchliger, 2016 $\left.{ }_{[2]}\right)$ (Bisciari, Essers and Vincent, $\left.2020_{[3]}\right)$. Only four out of 60 municipalities registered population growth over the past decade, namely the largest cities and the resorts along the Baltic coast (Figure $2 \mathrm{~A}$ ). Still rapid urbanisation was not sufficient to bring regional labour markets back to equilibrium: while structural unemployment in the urban areas was almost the same in 2007 as in 2018 (1.2\% against 1.4\%), it considerably increased in rural areas (1.9\% in 2007 against $3.3 \%$ in 2018), pointing at growing difficulties to match jobs with people (Figure 2 B). The poverty rate in urban areas is $19 \%$, while $31 \%$ in rural areas, with the gap increasing from $10 \%$ to $12 \%$ percent points between 2014 and 2018. 
Figure 2. Disparities are growing

A. Population growth in Lithuania's 10 counties Difference in population growth relative to national total, percentage points

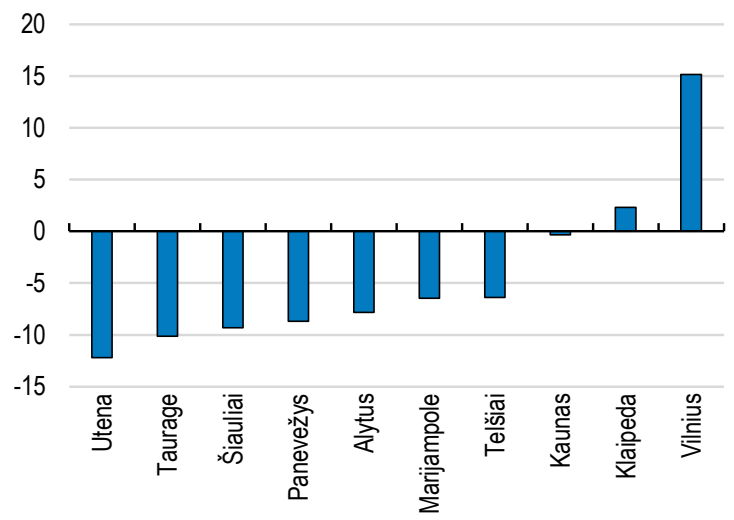

B. Regional unemployment

Long-term unemployment rate, $\%$ of labour force

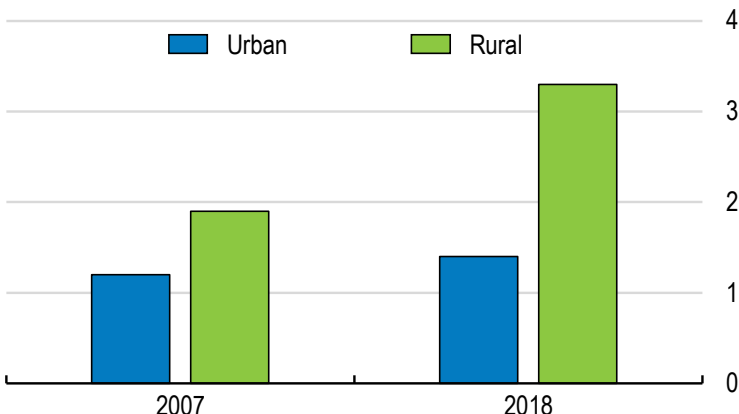

Note: Panel A: overall population in Lithuania decreased by $20 \%$ between 2000 and 2019; counties' growth is plotted relative to this general decline in population. E.g. Vilnius only saw its population diminish by $5 \%$ over the same period.

Source: OECD Regional database.

StatLink *ins https://doi.org/10.1787/888934185783

Economic and social imbalances are driven by rising economies of agglomeration, suggesting that metropolitan areas are the source of knowledge, innovation and productivity, as in most countries (Glaeser, $\left.2008_{[4]}\right)$. The gap between productivity in agglomerations and peripheral areas is rising, implying that highly productive activities concentrate in ever fewer places (Figure $3 \mathrm{~A}$ ), (Schwellnus et al., 2018 $8_{[5]}$ ). More than twice of per capita investment, including EU funds, is going to urban than to rural and peripheral regions (Figure 3 B). Around 25'000 FDI-jobs were created over the past five years in Lithuania, of which 16'000 in the capital area alone (Invest Lithuania, 2019[6]). The declining gap after the 2009 crisis is probably the result of a stronger cycle in wealthier regions, thereby reducing disparities in an economic downturn, although the pattern might again be different following the covid-19 pandemic (Smart, $2004_{[7]}$ ). Spillovers from more to less productive firms and regions, the core drivers of regional convergence, seem to be weak, suggesting a lack of knowledge transfer across regional borders.

\section{Figure 3. Agglomeration economies are at work}

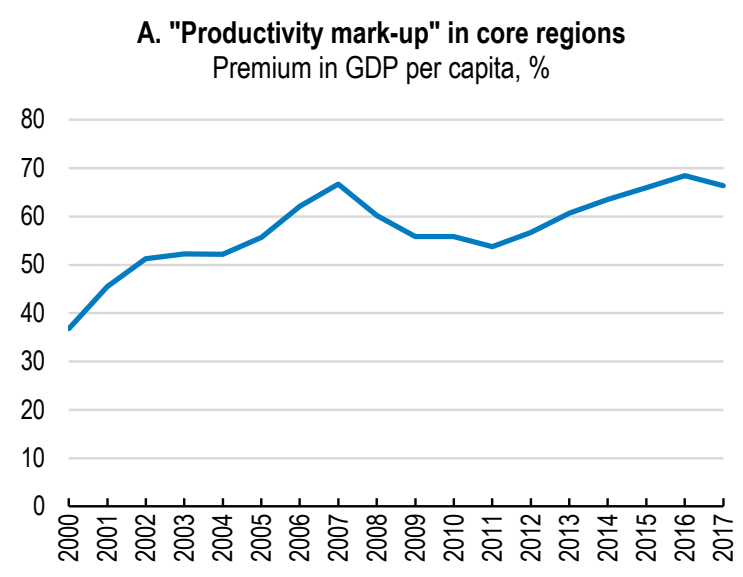

Source: OECD Regional database; and Ministry of Economy.
B. Total investment per capita by region EUR 1000s, 2010-2018

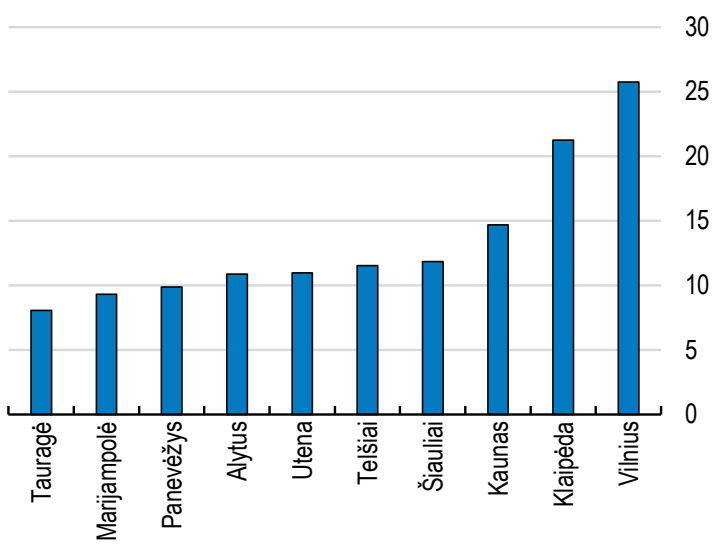

StatLink 제대 https://doi.org/10.1787/888934185802 
Lithuania's economic geography partly reflects the legacy of the Soviet planning system (PociuteSereikiene, Kriauciunas and Ubareciviene, $\left.2014_{[8]}\right)$. Soviet-era regional development consisted mainly of assigning industries to selected places and eliminating differences in living conditions between first- and second-tier cities. The economy was evenly developed across the country, sometimes creating specialized medium-sized "monocities" that depended on a single industrial sector or even plant (Blöchliger and Durand-Lasserve, 2018[9]). The town of Elektrenai - electricity plant - carries the name of its sectoral specialization. Labour mobility was restricted as workers were often assigned to a workplace. Industrialization went together with a tightly-knit network of public infrastructure such as schools, hospitals, cultural institutions and others, providing similar service levels across the country. When the industrial and spatial fabric unwound after renewed independence, public infrastructure followed suit more slowly, partly because the sector offered jobs in areas in decline. As a result, a shrinking population and a move to conurbations left large parts of the country with a dense but inadequate network of public services, sometimes referred to as "surplus infrastructure".

\section{Policies to foster regional convergence}

As a response to persisting regional imbalances, the government published a White Paper on regional development in 2017 (National Regional Development Council, 2017[10]). The strategy's main policy objective is to raise the growth potential of physical and human capital in each region through adequate institutional and governance reforms, rather than to redistribute wealth between rich and poor regions. The paper states two specific and actionable objectives, namely that citizens should be able to work within one hour of their residence, and that residents should have access to adequate public services within 30 minutes of reach. The development strategy brings up the concept of "functional regions", defined by regional labour markets or catchment areas of public services. Mid-2020 the parliament adopted a new law on regional development, establishing regional development councils as supra-municipal institutions that will implement national regional policy in the specific region and promote co-operation between municipalities.

The rest of the paper deals with the core policies that affect regional development in Lithuania. While urbanisation and agglomeration economies are fundamental drivers of regional growth and convergence, these drivers depend on and are amenable to policy (Tsvetkova et al., 2020[11]). Policies such as setting up physical and digital infrastructure, strengthening high and relevant skills to match local firms' needs, providing adequate housing for those moving to areas with more and better jobs, or else fostering the willingness and capacity of local governments to fund and provide adequate public service levels can help improve productivity, employment and well-being in each region. The paper will focus on transport and digital infrastructure, on housing markets, on education and on municipal public finance and their role for sustainable and inclusive growth across Lithuania.

\section{Fostering skills across the country}

Education and skills, key drivers of long-term development, vary significantly across Lithuania's regions. Differences in educational outcomes between core and peripheral regions belong to the deepest in the OECD, in a context of relatively low overall PISA outcomes. The extent to which students terminate secondary and VET education varies strongly across regions, contributing to differences in labour market outcomes. Skills mismatch is above the OECD average. Skills shortages vary across regions, with more productive regions usually having more labour shortages and a higher demand for qualified professions (Figure 4). Differences in the skills composition might be self-reinforcing, with some areas potentially becoming low-skill and low-income traps. In 2020 the government launched a requalification programme for highly-skilled professionals in all regions, thought to reduce skills mismatch. 
Figure 4. Demand for jobs is higher in more productive regions and for qualified professionals Vacancies and job seekers, 2019
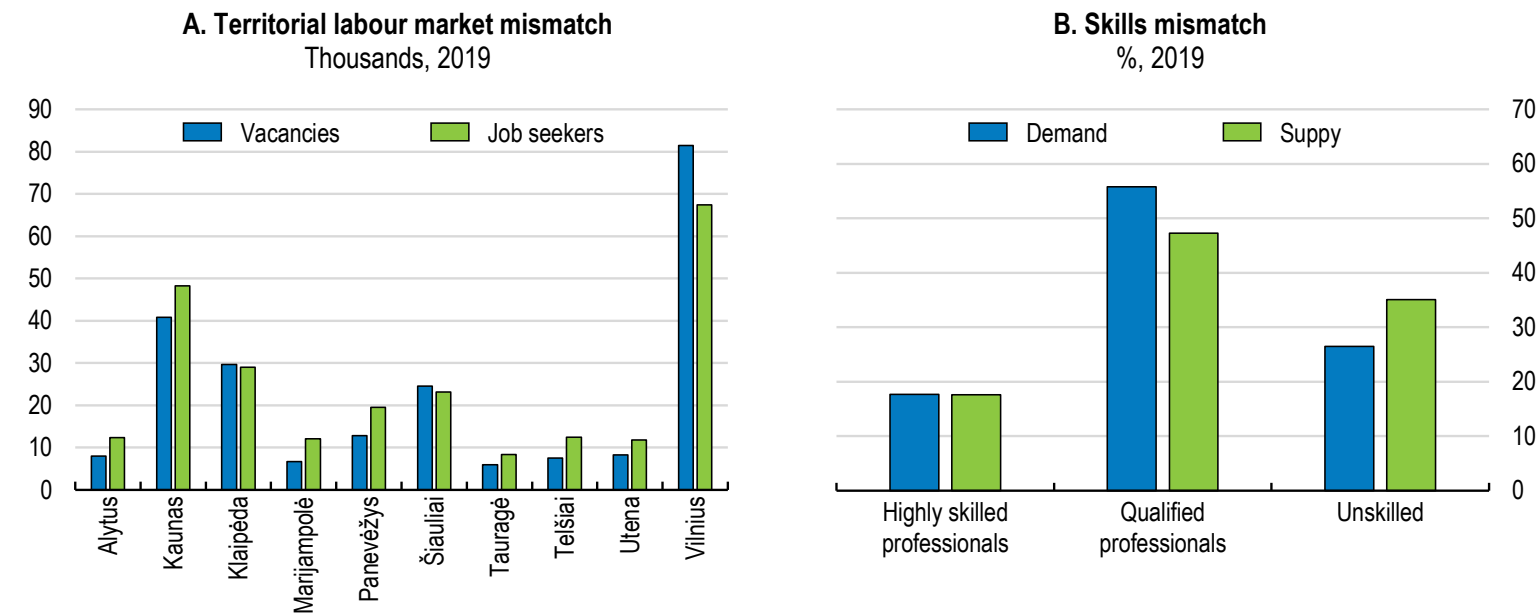

Source: Ministry of Labour and Social Affairs.

StatLink त्ञाज् https://doi.org/10.1787/888934185821

\section{The primary and secondary education system lacks scale}

Regional differences in PISA scores at the end of compulsory education are large, strongly driven by different levels of economic development (Figure 5). Urban/rural differences in socioeconomic and cultural status of pupils are especially wide; the performance of pupils from rural areas is persistently lower than that of urban students, and by a wider margin than is typical within the OECD. Low attendance in early childhood education in rural areas also contributes to the performance gap. Still, Lithuania is one of the few countries where rural students fare significantly better than urban ones if controlling for socialeconomic status. As such, more rural and peripheral areas are not per se disadvantaged by education policy and the school system. Rather, primary and secondary education could do more to improve outcomes and make up for disadvantages students are facing in all regions.

Figure 5. In Lithuania, urban-rural gaps in educational achievements are large

Difference in overall PISA score when living in a rural area, 2018

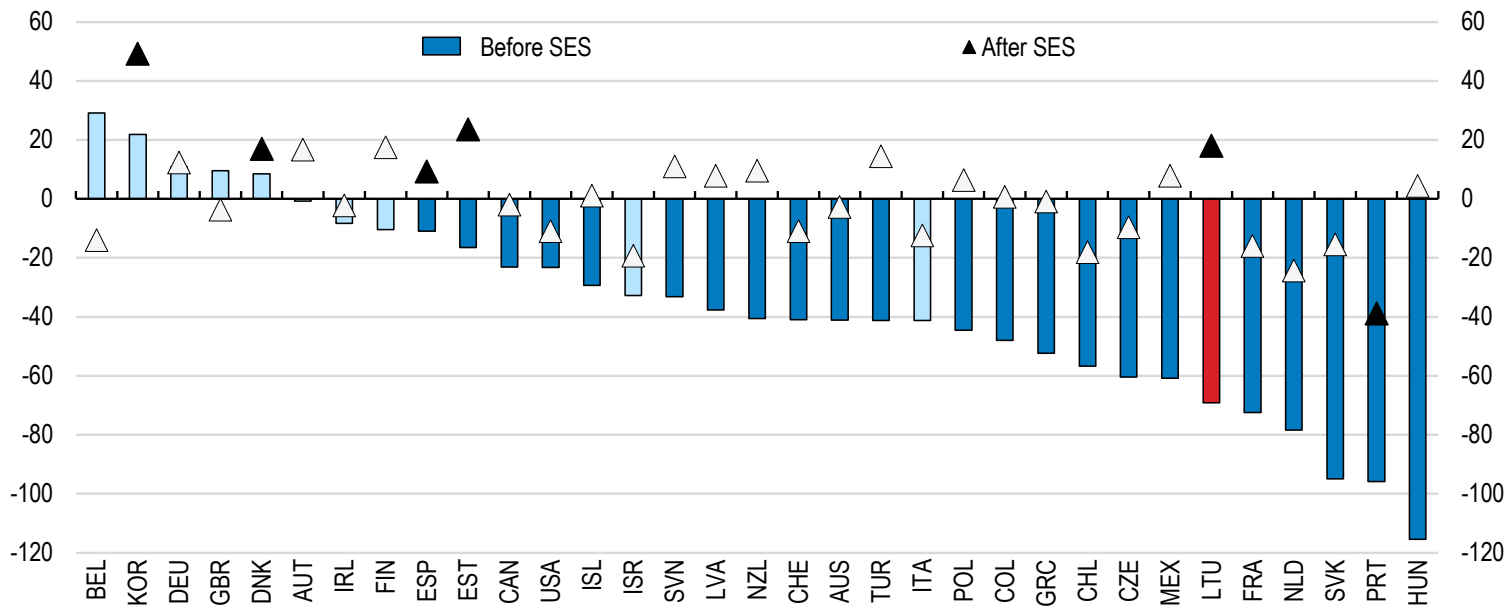

Note: Based on regression analysis using 2018 data from PISA. SES is the social and economic background of students. Darker shaded series are statistically significant.

Source: Based on: Echazarra and Radinger (2019), "Learning in rural schools: Insights from PISA, TALIS and the Literature", OECD Education Working Papers, No. 196. 


\section{Box 1. Are small schools responsible for low education outcomes? An empirical test}

Responsibility for primary and lower secondary education in Lithuania is split between several agencies. The Ministry of Education and Science is responsible for policy design and supervision and provides financial transfers to both municipalities and schools to cover current spending, known as the "student basket" or, more recently, "class basket". The 60 municipalities fund infrastructure and maintenance of the roughly 800 schools. A specialised body within the ministry develops the curriculum and teaching material; carries out country-wide test exams; and provides data for school monitoring.

To assess the school network's role for educational outcomes, the OECD carried out an empirical analysis, linking school and class size to 10th grade test scores at the end of compulsory education (Pagrindinio ugdymo pasiekimy patikrinimas or PUPP) (Figure 6). Funding per student was also included to assess the extent to which the funding formula reduces the role of school and class size for educational outcomes. Schools are divided into four types of regions, partly capturing student's socioeconomic background, which is strongly correlated with the urban-rural divide.

Results can be summarised as follows:

- School size and test scores are positively associated. This holds true for all types of regions, yet the association is strongest for urban schools, where a $10 \%$ larger school is associated with $1.8 \%$ better test scores.

- Funding plays an important role in improving test scores in all types of regions. Funding becomes more important the less "urban" an individual school. A $10 \%$ increase in spending in rural areas is associated with improved test scores of almost $3 \%$. In urban schools the increase is between 2.4 and $2.6 \%$.

- There is hardly any relationship between class sizes and test scores in any region, suggesting that class size has no clear impact on educational success.

Restructuring the school network until each school has at least 200 pupils would improve test scores by $9 \%$ overall or imply savings of around 10 Mill. Euro, not including less municipal infrastructure spending. The analysis covers the year 2019 , so captures the concurrent role of the school network. Its long-term role for student's success would require a panel data analysis covering several years.

\section{Figure 6. Smaller schools are associated with weaker outcomes and higher cost everywhere}

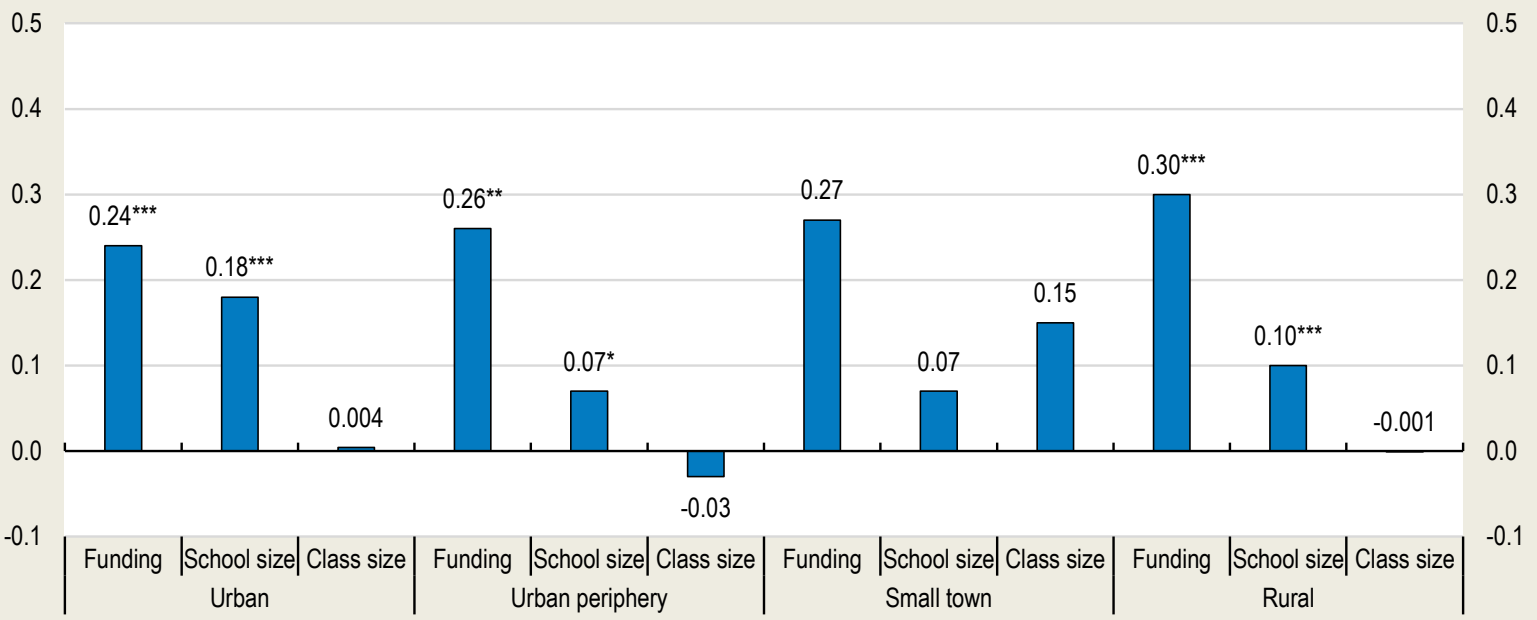

Note: Results show the estimated percentage increase in test scores for a one percentage increase in each independent variable, by type of region. Source: Ministry of Education, Science and Innovation. 
The gap in education outcomes is partly the result of an outdated school network with too many small schools and, to a lesser extent, small classes. The school infrastructure failed to adapt to declining student numbers (National Audit Office, 2017 $[12]$ ). In 2019 around $20 \%$ of all schools had fewer than 50 pupils, often taught in multi-level classes. Such fragmentation could negatively affect education quality and cost (Figure 7). First, educational outcomes tend to be weaker in smaller schools as education, in particular above the primary level, underlies scale effects. Larger schools can offer a broader curriculum, more specialised courses, and more interaction between and among students and teachers, generating knowledge spillovers (Shewbridge et al., 2016 $\left.{ }_{[13]}\right)$. In this vein, school restructuring, i.e. creating larger schools, generates educational benefits, especially at the secondary level. Second, smaller schools cost more per student. Lithuanian schools below 200 pupils seem particularly cost-intensive. Bringing each school to at least 200 pupils would mechanically improve test scores by $9 \%$ percent or imply savings of a total of around 10 million Euro per year, not including lower infrastructure spending borne by the municipalities (Box 1).

Figure 7. Educational outcomes in small schools are weaker, while cost is higher
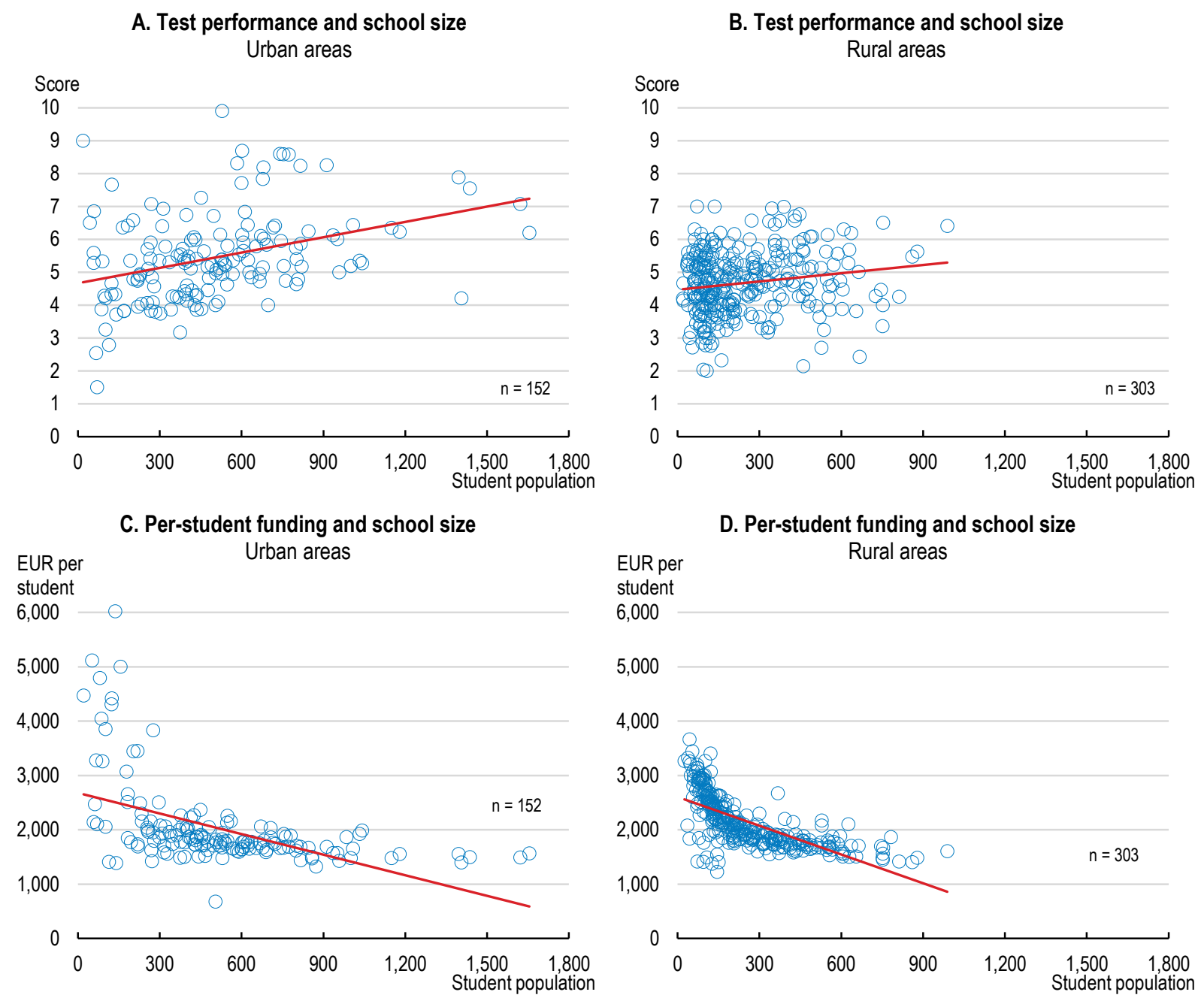

Note: Test scores are from standardised exams circulated to Grade 10 students and are scaled from 1 to 10 . Cost per student includes the ministry of education's total current spending allocated to municipalities and schools. These numbers do not include municipal spending on school infrastructure.

Source: Ministry of Education, Science and Innovation. 
The current funding system provides few incentives for municipalities to reorganise the school network and to improve schooling. Grants are unrelated to education outcomes, nor are schools regularly and systematically evaluated (National Audit Office, 2016[14]). In 2018 the Ministry of Education introduced a per-class funding system ("class basket"), replacing the former per-student funding ("student basket"). Although class-based funding leaves schools and municipalities sufficient flexibility in resource use, it considerably lowered incentives to increase school and class size and to help students with special needs (Shewbridge et al., 2016 ${ }_{[13]}$ ). Smaller schools receive larger per-student contributions, so a school merger reduces the level of funding for a municipality. Moreover, around $25 \%$ of schools, especially small ones, receive additional non-formula-based funds, lowering incentives to reorganise even further. The Ministry of Education has little direct influence on the school network since infrastructure and maintenance is under the sole responsibility of the municipalities.

Political economy constraints make school mergers challenging to implement. Municipalities tend to resist mergers since this is seen as cutting access to a core public service. In 2018 and 2019 the government had to backtrack on planned restructuring and has become more cautious. The recent change in school organisation, namely assigning one head teacher to several schools, is a welcome first step towards reaching higher school quality. Lithuania will soon face a shortage of teachers as many approach retirement, facilitating further reorganisation. The government should hence continue school network reform, essentially by applying appropriate funding formulas and improving school monitoring, while weighing the benefits of school reorganisation against drawbacks such as a longer way to go to school or the loss of community life. Overall, the share of spending for teaching, especially digital skills, should rise, while infrastructure spending should decline.

\section{Vocational education and training should better match local labour market needs}

Vocational education and training (VET) helps students develop professional skills in upper- and postsecondary education. VET, which integrates school- and work-based learning, provides a strong link between students and the business sector. VET is more reactive to local and regional labour market needs and is associated with less skills mismatch. In countries with a strong tradition of professional education, post-secondary VET improves protection against unemployment and inactivity, especially for the youth, and labour market outcomes such as wages or employment levels are often better than those of comparable academic programmes (OECD, 2014[15]) (OECD, 2018[16] $)$.

Lithuania has one of the lowest enrolment rates in VET with around $27 \%$ of all students in upper secondary education (Figure 8). VET has a relatively poor reputation with students, although many university students start VET after graduation, pointing at the relatively strong value of professional rather than general education (OECD, 2017[17]). Upper secondary vocational education has struggled to increase its attractiveness to learners, and to provide them strong labour market outcomes (National Audit Office, $\left.2016_{[18]}\right)$. Curricula are too constrained by the interests of training providers and not sufficiently driven by fast-changing business requirements, generating skill and labour market mismatches. Since VET is relatively more important outside the large conurbations, the more peripheral areas are relatively more affected by the low level of professional education. To improve the reputation of VET, the government in 2017 established a pathway from upper secondary vocational studies to tertiary education, yet few upper secondary graduates follow this path.

The government has reacted to weaknesses in the VET system and is improving the vocational curriculum. The new VET law of 2017 brought significant changes likely to increase labour market performance of VET, in line with recommendations of the last Survey. Reforms include:

- Establishing sectoral professional committees comprising employers, employees and education providers, to approve vocational standards and assess vocational training programmes

- Strengthening business association's participation in the governance of VET schools through school self-governing councils. 
- Strengthening financial autonomy of VET schools

- Broadening access to VET, with new flexible and modular programmes based on learning outcomes rather than length of the programmes.

\section{Figure 8. Vocational education and training, including apprenticeships, is weak}

Share of school- and firm-based education in total upper secondary education, 2018 or latest year, \%

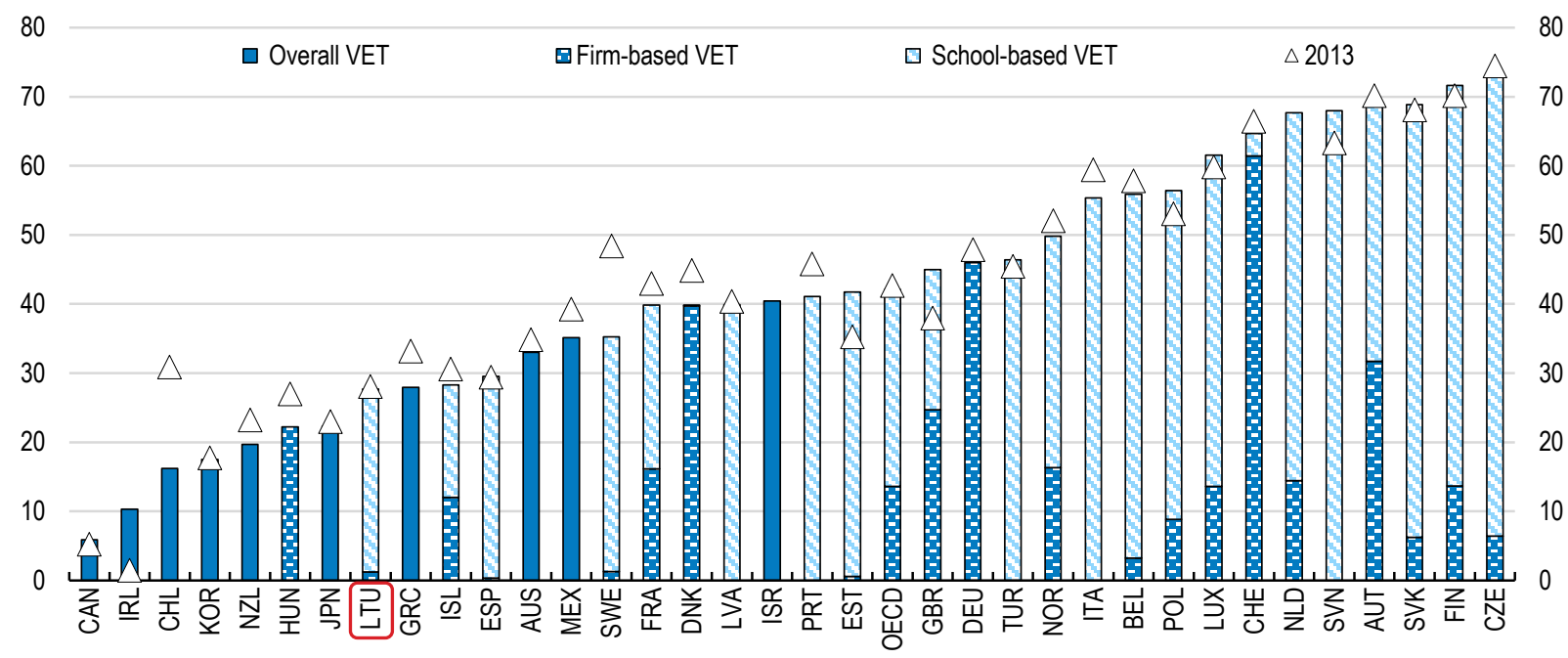

Source: OECD calculations based on OECD Education at a Glance database and European Center for the Development of Vocational Training (CEDEFOP) database.

StatLink : जाls https://doi.org/10.1787/888934185897

To meet its own target of rising the share of upper-secondary VET students in all students from $27 \%$ in 2016 to $35 \%$ by 2022, Lithuania should continue to invest in the development and modernization of VET infrastructure, including by reorganizing schools and training centers to reach economies of scale and scope in rural areas. Performance of the VET system should be regularly assessed, especially with respect to labour market outcomes, and curricula adapted if appropriate. Finally, VET should offer more pathways towards other curricula, especially tertiary education, as is increasingly done in France, Germany and Switzerland.

Importantly, firm-based learning - apprenticeships or "dual system" - should be made more attractive. The attractiveness of firm-based learning relies on a few factors such as the apprentice wage, the value of the professional certificate, the duration of the apprenticeship and the alignment with school-based VET education (Moretti et al., 2017 ${ }_{[19]}$ ). In other words, firm-based learning works if employers have an incentive to offer and students to take up apprenticeships. In Lithuania, where employer resistance to apprenticeships is considerable because of the cost-free school-based VET system, government could nudge them with some additional incentives such as limited financial support or the creation of an employer-managed training fund. The administrative burden should be kept low, which is important for smaller employers. The dual system should be developed in close partnership with industry stakeholders and local governments. In this vein, stakeholders should create platforms - including in the recently setup regional councils - for standard setting, assessing programmes, and collective bargaining (Box 2). Going beyond the traditional technical realm, apprenticeships could extend to new areas like health care or tourism, particularly suitable in regions with an ageing population or tourism resorts. 


\section{Box 2. Implementing firm-based learning successfully}

The significance of firm-based professional learning - apprenticeships - varies widely across OECD countries. For example, Lithuania counts around 900 apprenticeship contracts, while Finland counts $50^{\prime} 000$ or Austria $110^{\prime} 000$. On average around $80 \%$ of upper-secondary vocational education has the form of firm-based learning or apprenticeships in the European Union.

Building apprenticeships in countries where they are uncommon like in Lithuania, creating new programmes in sectors that typically rely on other forms of training, and ensuring labour market relevance is challenging. Experience from countries with strong apprenticeship systems - e.g. Austria, Denmark, Germany, Hungary or Switzerland - suggest a few guiding principles for effective firm-based learning:

- Social partners, i.e. trade and employer organisations and trade unions and their regional counterparts must be involved in the design and implementation of apprenticeship schemes. "Ownership" is essential to encourage their willingness to provide placements.

- The attractiveness of apprenticeships and alternative learning pathways such as school-based training or academic tertiary education should be balanced, and competition between different learning pathways should be fair.

- Diplomas and other forms of formal qualification must bring substantial benefits to apprentices

- The main parameters of apprenticeship schemes must remain flexible to ensure that an apprenticeship remains attractive to both potential employers and apprentices.

- Costs and benefits of apprenticeships should be monitored to inform the design of new schemes and the reform of existing schemes.

The sub-national context matters, especially as the regional industrial structure or average firm size may determine varying needs across regions and districts. To take local labour market needs into account, a part of the apprenticeship arrangements could be negotiated locally, e.g. by involving the regional councils planned in the new law on regional development.

Source: (OECD, 2018[16]) (European Commission, 2012[200])

\section{Universities should specialise more}

The tertiary sector suffers from the problem of "surplus infrastructure" as well. With 19 public universities and 22 colleges, Lithuania's tertiary institutions struggle to reach scale, performing well below OECD averages with respect to research and innovation (OECD, 2017 $[17])$. Recent attempts to consolidate the network have failed as the Ministry has no power to merge tertiary educations, and mergers that were carried out did not bring the expected results. The government is currently preparing new legislation providing universities with more incentives to deliver on quality and closer to the labour market, hoping that consolidation will then happen from universities' own interest. The student voucher system will be adapted to partly reflect the number of graduates rather than students.

Given Lithuania's size and geography, the country should continue scaling down the number of universities and colleges, with smaller ones potentially being regrouped under a joint leadership or becoming subsidiaries of larger institutions. A combination of university closures and reorganisation could accommodate political economy concerns about an even distribution of higher education institutions across the country. The remaining campuses should specialise in fewer study areas to reach critical mass and to avoid overlap and duplication. Finally, strengthening collaboration between firms and universities and colleges could also help strengthen links to regional labour markets. This could be achieved by increasing 
incentives for firms to invest in research in universities - and for universities to endorse such funding -, thereby raising funding which is currently low (Figure 9).

\section{Figure 9. Firms contribute little to university funding in Lithuania}

Share of public, household and corporate private funding at tertiary level, 2018

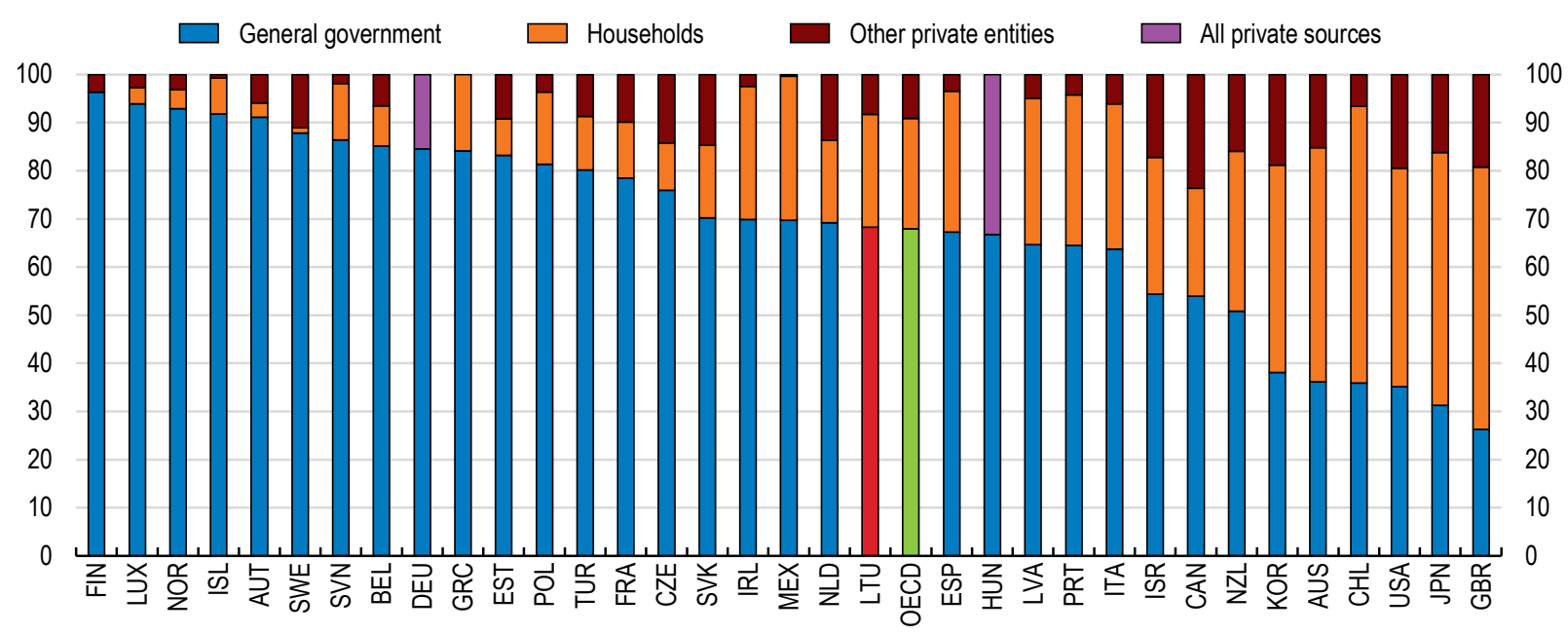

Note: Excludes international expenditure on tertiary education.

Source: OECD Education at a Glance database.

\section{The national minimum wage particularly affects regions with many low-skilled workers}

Minimum wage legislation may require policy responses to increase skills of low-skilled workers. The Lithuanian minimum wage is relatively high compared to the median. More importantly, its bite varies strongly across regions, affecting less than $40 \%$ of wage earners in the capital and more than $55 \%$ in other parts of the country (Figure 10). These differences might affect employment across regions. Research for Germany, which introduced a minimum wage in 2015 , suggests that minimum wages reduce employment in regions with a high share of low-skilled, low-income jobs, while regions with a large share of well-paid high-skill jobs are hardly affected (Dustmann et al., 2020 ${ }_{[21]}$ (Bonin et al., 2019[22]). Such an asymmetric effect of the minimum wage could hence explain more rapidly rising unemployment in regions with fewer high-skill and high-productivity jobs in Lithuania (Figure 2B). Against this background, the government should pursue education and skills policies that help improve productivity and hence reduce the bite of the minimum wage in low-skill regions. Another option is to regionalise the minimum wage, as before the labour market reforms of 2017. 
Figure 10. The minimum wage has a strong bite in less productive regions

Ratio of minimum wage to average gross wage by county, 2019

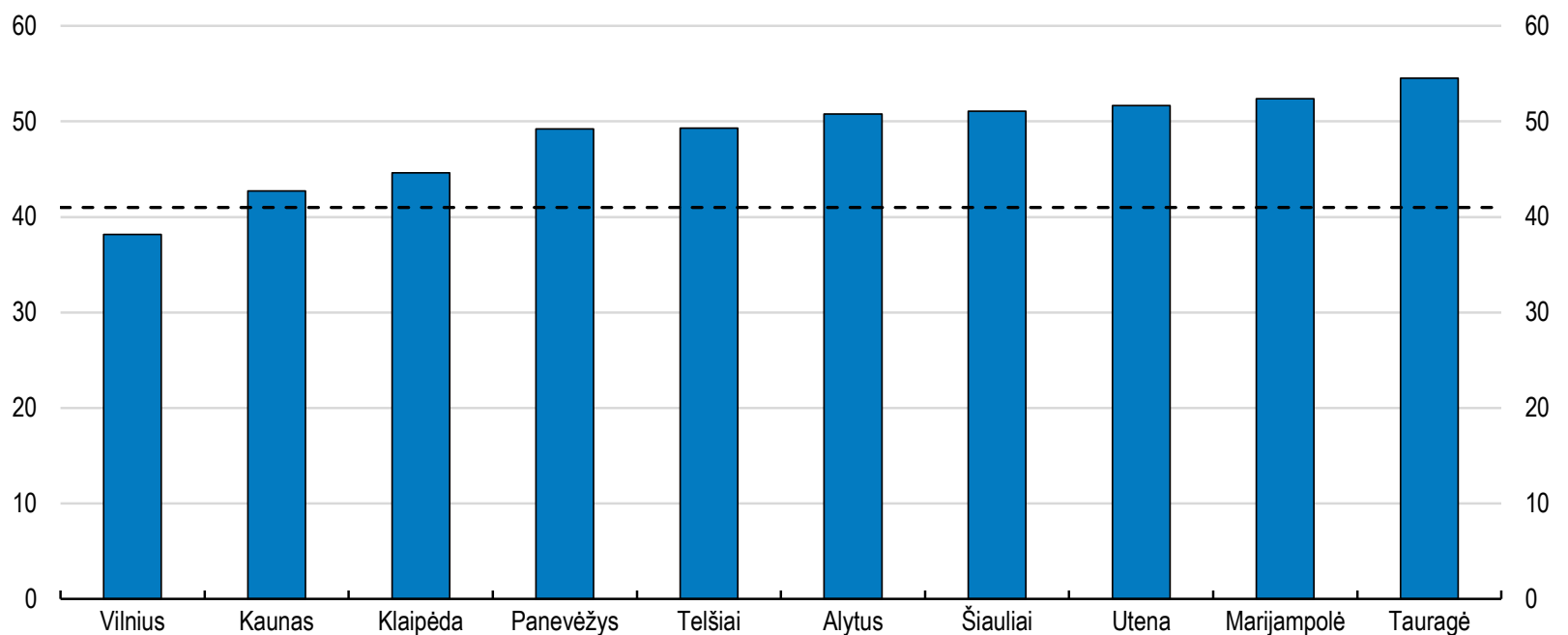

Note: the $41 \%$ horizontal line reflects the national average.

Source: Statistics Lithuania; and Lithuania Free Market Institute.

StatLink הताst https://doi.org/10.1787/888934185935

\section{Investing in sustainable infrastructure}

\section{Transport should be improved and become more sustainable}

Lithuania's transport infrastructure remains below OECD standards, despite high investments largely covered by European Union funds (Figure 11). Transport is dominated by an international East-West axis linking Russia and Europe, while South-North infrastructure is underdeveloped. Efficiency in the rail sector is low, and road fatalities, albeit decreasing, are high, partly owing to inadequate road infrastructure. Moreover, transport is responsible for above-average amounts of $\mathrm{CO}_{2}$ emissions (see green growth background paper). With regard to local and regional transport, several studies point at low accessibility in and around conurbations, mainly due to congestion (Jakimavičius and Burinskiene, 2007[23]), (ESPON, $2015_{[24]}$ ). Investment is focused on international projects such as Rail and Via Baltica, thought to improve links between the Baltic states and Central, Western and Northern Europe. Against this background, improving sustainable local and regional transport infrastructure, especially in urban areas, is an essential ingredient to raise productivity and well-being across regions. 
Figure 11. Transport infrastructure needs improvement

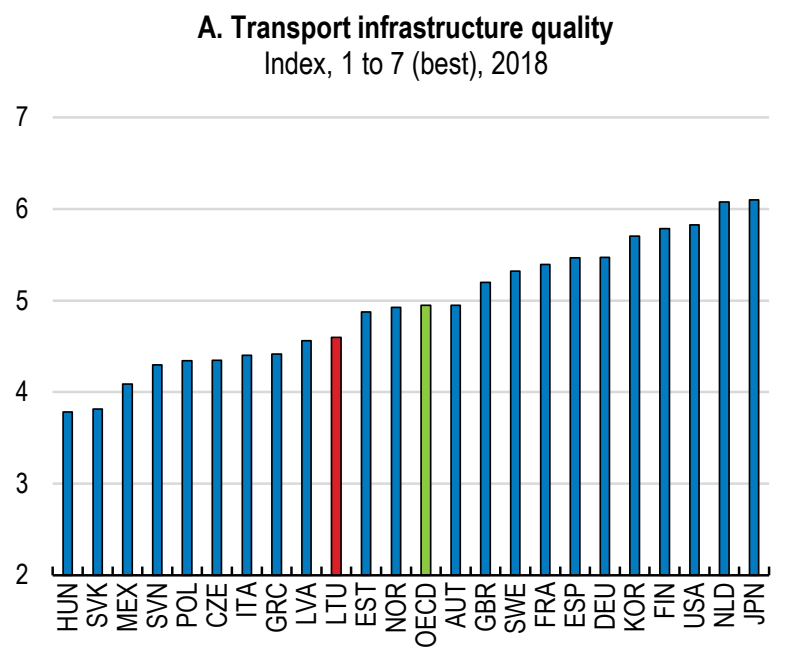
B. Average investment level $\%$ of GDP, 2012-2018

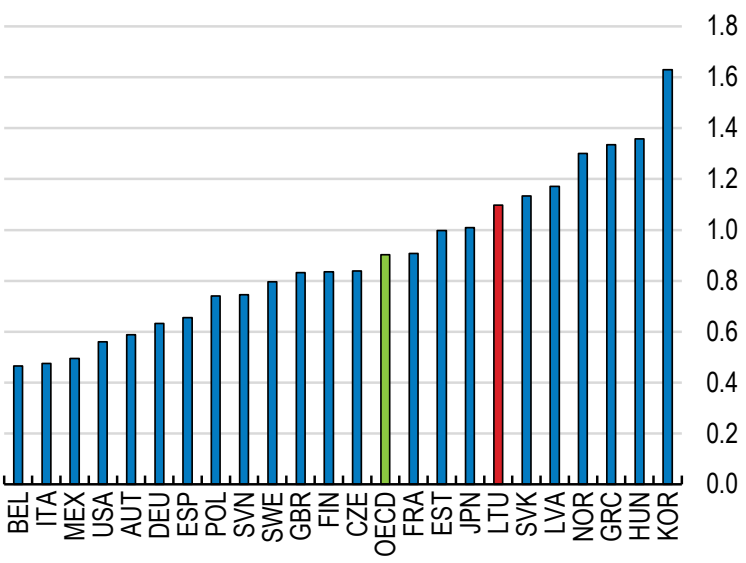

Note: Panel A: overall indicator is the simple average across four sub-indicators: Quality of Roads, Efficiency of Seaport Services, Efficiency of Air Transport Services, and Efficiency of Train Services. Averages are calculated for the most recent value of all countries with available data (unweighted).

Source: World Economic Forum Global Competitiveness Indicators 2019; OECD Transport database; and OECD Economic Outlook database.

StatLink तiाs https://doi.org/10.1787/888934185954

Local and regional public transport still suffer from neglect after renewed independence, despite having improved over the past few years (European Commission, 2019[25]). Lacking investment and fragmented decision making across municipalities have prevented the development of adequate public transport networks, especially in urban areas. Rail has almost no role in urban transport. For that reason the National Transport Development Plan identified investment into sustainable urban transport as one of the five priorities to improve the transport and communication system (Ministry of Transport and Communications, $\left.2014_{[26]}\right)$. Since local and regional public transport in Lithuania is mainly by bus, a high-quality bus network and innovative solutions such as a stronger reliance on ride-sharing in sparsely populated areas could help increase accessibility and reduce private car use responsible for congestion and declining environmental quality (Box 3.1). Since higher transport quality increases real estate values, transport investment could be partly financed through higher property taxes as in the United States (Gupta, Van Nieuwerburgh and Kontokosta, 2020[27]).

Appropriate pricing of transport infrastructure can help manage demand, address environmental damage, and provide funding for new infrastructure, especially in the context of declining EU payments as planned from 2021. Medium-sized cities such as Bergen or Trondheim in Norway introduced road pricing schemes as early as the 1980s, to help fund infrastructure upgrades (International Transport Forum, 2010[28]). In Lithuania's larger cities, road-pricing (or mobility pricing) could support environmental policy, e.g. by differentiating prices according to emissions, or it could help fund public transport infrastructure such as dedicated bus lanes. Given the political economy headwinds for pricing schemes, their benefits should be clearly visible, for instance in the form of better infrastructure both for public and private transport or higher environmental quality. Road pricing could complement $\mathrm{CO}_{2}$ taxes, and it might compensate revenue from fuel taxation which could decline by $25 \%$ over the next 10 years as private transport moves towards electric cars (OECD/ITF, 2019[29]). 


\section{Box 3. Modernising local and regional public passenger transport}

Following rapid urbanisation, rising car ownership and lacking investment, most Central and Eastern European economies have witnessed a dramatic decline in the use of public transport over the past twenty years. Urban public transport was entirely disbanded in some areas, with a fragmented and poorly regulated private minibus ("marshrutka") market replacing the former public operators. Poor service quality tended to exceed potential efficiency gains arising from competition among operators. In the more rural and peripheral areas, low demand following population decline and strong reliance on private cars made it difficult to sustain public transport services, or only at high cost.

Under these circumstances, policy measures to improve public transport, in particular to encourage commuting, should build on different approaches depending on population density.

- Densely populated areas: Integrated transport systems have proven the most effective way to improve urban public transport. Network externalities arising from congestion, density and environmental impact call for organisation by a single agency, with routes, timetables and fares based on cost-benefit analysis. Since urban public transport in Lithuania is overwhelmingly by bus, the regulatory framework should allow for efficient service provision, with operation of the network or parts of it being tendered. Investment should focus on separate bus lanes and fast high-quality buses. Kaunas, Lithuania's second city, in 2013 integrated the minibus system into the urban public transport network, considerably increasing quality at almost no additional cost.

- Sparsely populated areas: Traditional public transport lacks flexibility and scale in peripheral areas to remain sustainable. As such, the government might initiate new transport on demand concepts. Demand-responsive transport has shown promising results in Norway, providing door-to-door services at the user's desired time rather than with a fixed route and timetable. Car- and ride-sharing services can suit markets in peripheral areas. In 2017 Innisfil, a rural town in Canada, was the first to hand over responsibility for public transport entirely to a ride-sharing operator. To save cost and improve services, the government might also bundle different transport providers, e.g. combining municipal buses with the yellow school buses or the postal service, jointly funded by the responsible agencies.

Finally, regulatory reform in the transport sector, including harmonised rules for concessionary services and tendering bus services, joint tendering across municipal borders, and a more flexible taxi licencing system, could help underpin better public transport in all areas.

Source: (European Bank for Reconstruction and Development, 2019[30] $)$, (Dotterud and Skollerud, 2015[31]), (OECD, 2017[32] ), (The Guardian, 2019[33])

Finally, competition and regulatory reform could help improve transport services and reduce gaps in accessibility between regions. (OECD, 2016[34]). The state-owned rail company LG still dominates transport services, which is important given that rail accounts for $34 \%$ of freight transport, against $16 \%$ in the European Union. In 2017, the European Union fined LG for anti-competitive behaviour, and despite open access, there is no private provider of rail passenger services. Buses operate on an open-access basis, yet municipalities are not obliged to tender bus services, and they hardly collaborate to provide joint services, which often results in insufficient network size and low service quality (Lithuanian Free Market Institute, $2019_{[35]}$ ). If hail-riding apps are to become a new form of public transport, concession rules must ensure all operators are treated equally. In order to strengthen competition further and to allow regional transport operators reach scale and scope, regulation could be harmonised across the three Baltic countries. The Rail Baltica and Via Baltica projects could be an opportunity to set up a single trans-Baltic transport competition and regulation authority. 


\section{Digital infrastructure should be improved in rural areas}

Digital transformation and upgrades foster higher productivity and well-being (OECD, 2019[36]). Crosscountry regressions suggest that boosting high-speed Internet connections by $10 \%$ would boost productivity directly by $2 \%$, while adoption of cloud computing and other advanced digital technologies would add another $1.5 \%$ to productivity, although these gains are stronger for more productive firms and weaker in the presence of skill shortages (Gal et al., 2019 ${ }_{[37]}$ ). In Norway, higher broadband connection increased online vacancy-postings and lowered the average duration of a vacancy and the share of establishments with unfilled vacancies (Bhuller et al., 2019 ${ }_{[38]}$ ). The covid-19 crisis has revealed the benefits of a well-developed digital infrastructure across all regions of a country enabling teleworking and improving access to public administrations.

Broadband coverage and uptake are well advanced in Lithuania on average, but the digital divide between regions is wide (Figure 12). Fixed broadband coverage of households is still below the European Union average, but rising steeply. As one of five OECD countries only, fibre provides the majority of broadband connections. The mobile phone network is well-developed and advanced. The use of digital tools by businesses is above the OECD average. Broadband prices are among the lowest in the European Union. However, he lack of fast broadband connectivity in rural areas prevent parts of the population from taking advantage of the digital and technological transformation, and digital skills remain below the EU average (European Commission, 2020[39]). Urban-rural divides in access occur for a variety of reasons including fixed broadband, in particular of higher speeds, not extending to some rural areas as well as low uptake.

\section{Figure 12. The digital divide between regions is stark}

Share of households with fixed broadband Internet access at home, 2019 or latest available year

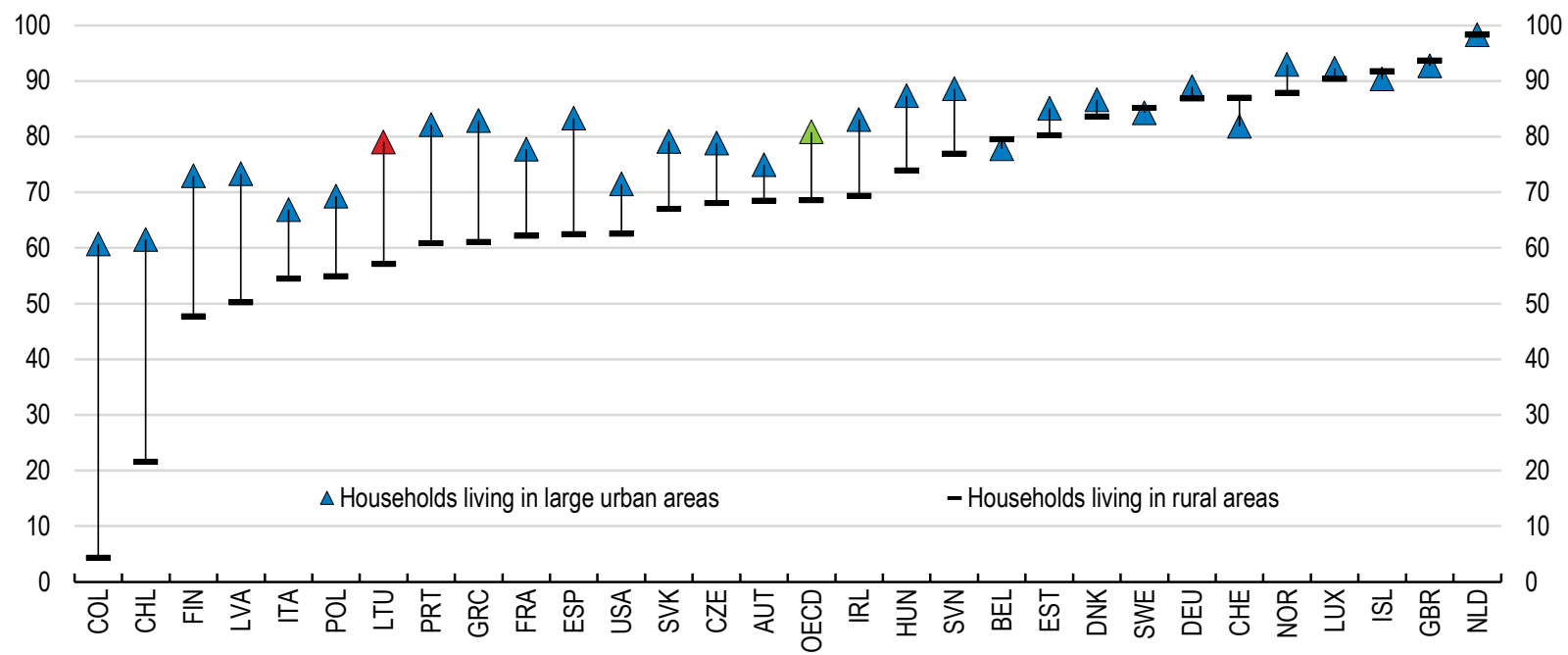

Source: OECD Information and Communication Technology database.

StatLink 제개 https://doi.org/10.1787/888934185973

Since 2005 Lithuania has used an array of EU-funded programmes (RAIN, Rural Area Information Technology Broadband Network) to improve digital access in remote and sparsely populated areas. The Ministry of Transport and Communications is currently implementing the Next Generation Access Infrastructure (NGA) to ensure high-speed access. Lithuania should continue reducing the digital divide between urban and rural regions - among others to allow for more teleworking in the countryside -, thereby following recent recommendations of the OECD to ensure efficient coverage (box 3.2).Since digital 
services can be provided by different technologies - fixed line broadband, mobile, wireless, and satellite connections -, the government should establish a technology-neutral policy, i.e. a regulatory and funding framework that focuses on outcomes - namely connectivity - rather than a specific type of infrastructure. Finally, digital skills to help households and business make use of new infrastructures should be improved, especially in rural areas.

\section{Box 4. How to bridge the digital divide between urban and rural regions?}

Most OECD countries have established specific policies to expand high-speed connectivity in rural and remote areas. However, challenges remain, especially with respect to the cost of improved broadband in regions with low population density as well as the need to enhance the use of digital services. Against this background, in 2018 the OECD published a set of benchmarks and best practices to improve access to and use of broadband in sparsely populated regions. The recommendations based on experience in Australia, Canada, Denmark, Ireland, the United Kingdom, and Sweden can be summarised as follows:

- Understand the existing broadband gaps: Measure the different availability and adoption gaps through indicators and maps, and make information on connectivity and prices available to consumers and operators

- Foster sound regulatory frameworks: Establish technology-neutral and consumer-centred regulatory frameworks that rely on clear rules for all market actors and enable fair competition

- Streamline administrative procedures: Improve co-ordination across levels of government and eliminate administrative redundancies, to reduce deployment costs

- Enhance access to networks: Remove existing barriers to access infrastructure, such as restrictive rights of way, limitations of access to poles, ducts etc. Promote open access networks if they involve public funding

- Stimulate local and municipality level initiatives: Implement bottom-up models to finance and deploy high-speed networks, such as those of municipal or community networks

- Foster demand and adoption of broadband services: Foster the use of broadband-services, through awareness, affordability, digital literacy, relevant content and trust.

- Improve dialogue between private and public sectors: Governments and regulatory authorities should engage in dialogue with market actors to reach a common understanding of how best to improve coverage and to improve digital skills

Source: (OECD, 2018[40])

\section{Scaling up housing, while reducing urban sprawl}

House prices in Lithuania are low, but differ more across regions than in other Central and Eastern European countries (Figure 13). Residential mobility has resulted in markedly stronger demand and higher house prices in economically dynamic areas. Although housing supply is elastic overall, in some fastgrowing cities with good amenities, construction could not keep up with rising demand, slowing migration towards more productive places. Also, affordable housing has become an issue in the capital area of Vilnius (Binovska, Kauskale and Vanags, 2018[41]). 
Figure 13. House prices are low in Lithuania but vary across regions

Price per square metre, by region, EUR 1000s, 2019

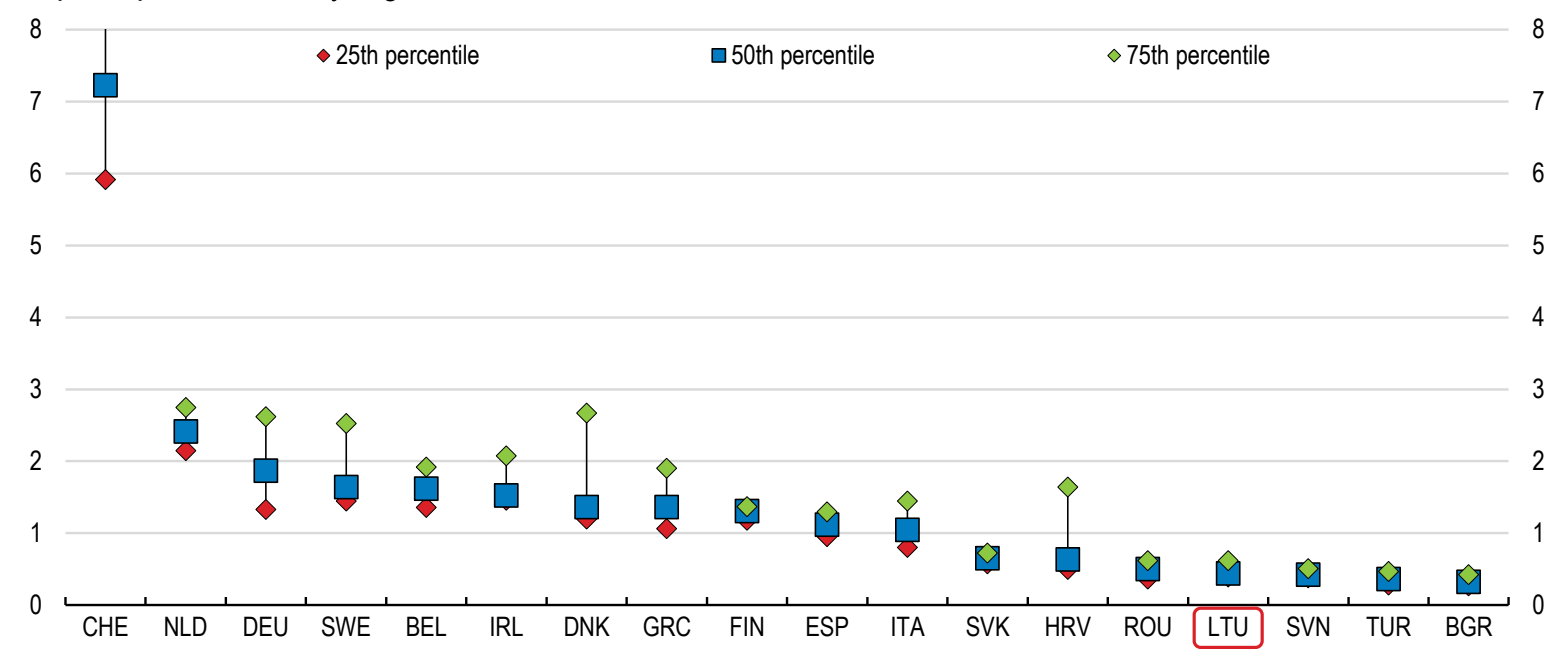

Source: European Union, Houselev database.

StatLink त्ञाज https://doi.org/10.1787/888934185992

\section{High ownership rate is likely to reduce labour mobility}

At $90 \%$, Lithuania features the highest homeownership rate of the OECD besides Slovakia (Figure 14). In rural areas virtually all homes are owner-occupied following mass privatisation after renewed independence. While owner-occupied houses and apartments are an asset, they are also an obstacle to residential mobility. Recent OECD research suggests that homeowners are much less mobile than renters (Causa and Pichelmann, forthcoming[42]). Financial constraints reduce the capacity to move: selling a house in the countryside generally does not provide sufficient financial resources to buy appropriate accommodation in urban areas. The mortgage market is rather shallow, reducing further incentives to accept jobs that require moving residence to meet mortgage payments (Andrews et al., 2011). Against this background, improving residential mobility is an important policy challenge for more balanced regional development.

Figure 14. High home ownership rates could create a barrier to labour mobility

Share of owner-occupied housing, percent of total housing, 2018

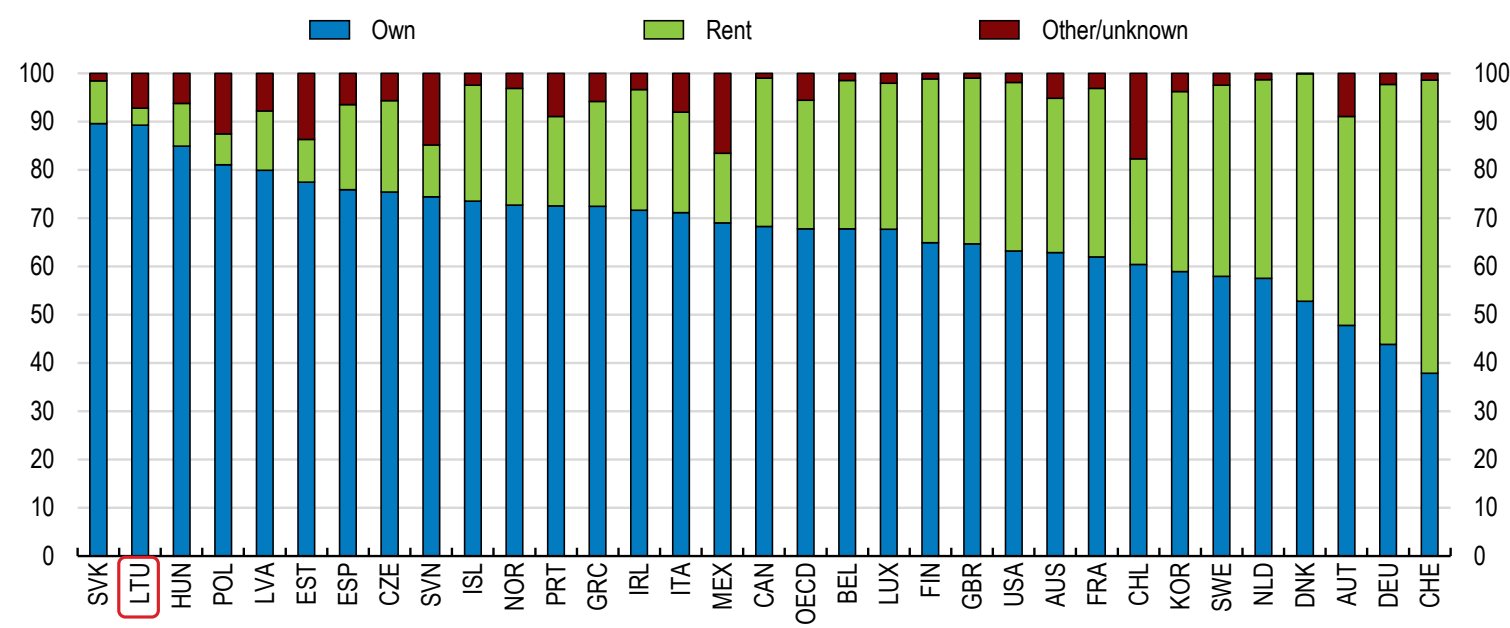

Source: OECD Affordable Housing Database.

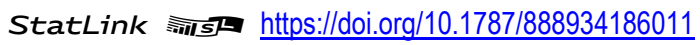


The small rental market is an additional barrier to residential mobility, prompting labour market "lock-in" effects (Glocker and Plouin, 2016[43]) (Andrews and Caldera Sánchez, 2011 ${ }_{[44]}$ ). Less than $10 \%$ of the Lithuanian population lives in rental housing, compared to $25 \%$ in the European Union (Eurostat, 2019 ${ }_{[45]}$ ). Renting is mainly for mobile high-income households, unlike in other European countries where the rental market targets low- and medium-income households. Complex and opaque regulation could be a reason for the lack of rented dwellings. Constitutional law protects both "integrity of the home", especially for families, and individual property, raising insecurity for both tenants and landlords. As a result, owners set higher rents to price in risks of financial losses, or rent out informally $(70-80 \%$ of renting might be informal according to the authorities). To deepen the rental market, to increase residential mobility and to improve housing affordability, the government should strive for a reform of the civil code that clarifies and enforces rights for both renters and owners.

Fragmented ownership adds another problem. Lithuania's housing stock consists for a large part of multiapartment dwellings built during the Soviet era, privatised to individual dwellers after renewed independence. Fragmented ownership of these buildings makes management and coordination of upgrading works difficult as an absolute majority of dwellers need to consent. Moreover, many owners have limited financial resources and access to credit. As a result, renovation and maintenance work is often insufficient, leaving many apartments without basic facilities, especially in rural areas (Figure 15). Moreover, while the area-heating system functions well, residential energy consumption is high since dwellings are badly insulated. In 2019 the government amended the law on support of multi-apartment houses and increased contributions especially for improving energy-efficiency which had been modest in the past few years. Creating a housing fund, akin to the State Housing Development Fund in the Slovak Republic, could be an effective way to improve quality and energy-efficiency of dwellings (Box 5).

\section{Figure 15. Many apartments need upgrading}

Share of population living in facilities without basic infrastructure, 2017

30

25

20

15

10
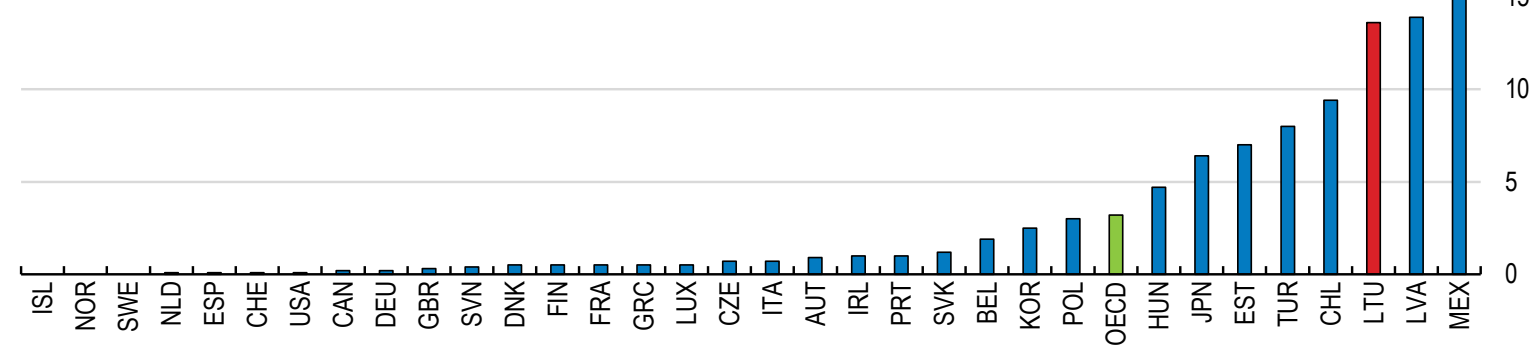

Note: Basic facilities refers to having an indoor flushing toilet for the sole use of the respective household. The index includes single-family houses, where the issue is more prevalent than in multi-apartment dwellings.

Source: OECD Better Life Index. 


\section{Box 5. The Slovak Republic's State Housing Development Fund}

Slovakia's State Housing Development Fund, introduced in 1996, is a key tool in supporting the expansion of property and rental housing and improvements to housing quality. The Fund provides favourable long-term loans, financing up to $100 \%$ of acquisition costs for up to 40 years. Loans can be accessed by individuals, local governments and not-for-profit organisations. The Fund also helps to finance the acquisition of rental dwelling as well as the renewal or upgrades of residential buildings. The Fund was initially funded almost entirely through the state budget yet has progressively become self-sufficient while doubling its initial capital.

In recent years the Fund has been effective in funding maintenance and refurbishments. As of 2016, approximately half of the country's dwelling stock had been refurbished. Around $25 \%$ of the total housing stock have been refurbished with the support of the Fund. The Ministry of Transport and Construction, which manages the Fund, has been very active in engaging with housing managers and associations of owners to explain the opportunities offered by the Fund. Financing is provided after the presentation of a technical assessment, which has further contributed to better understand the state of the housing stock and raise awareness of the need to intervene.

To complement the Fund, a housing development programme, introduced in 1998, provides subsidies to municipalities to finance i) the construction of social rental housing; ii) the construction of technical infrastructure; and iii) the elimination of systematic technical failures in building construction. Depending on the building features and quality standards, the subsidies to municipalities can cover between 40 and $75 \%$ of the acquisition costs.

Source: (OECD, 2020[46])

\section{Fostering sustainable urban housing supply could facilitate mobility}

International experience suggests that flexible housing supply can be a powerful tool to facilitate mobility towards high-productivity areas, while keeping local house price excesses at bay (Glaeser and Gyourko, 2018[47]). Housing supply, i.e. new construction, seems not to have kept up with rising demand in economically active areas, although OECD supply-side elasticities do not exist for the Baltic countries (lacovos, 2018[48]) (Cavalleri, Cournède and Özsögüt, 2019[49]). The share of new construction in the total housing stock is below the OECD average (Figure 16). The land use planning process and issuance of construction permits can be slow and prone to mistakes, heightening insecurity and cost for firms and households (National Audit Office, 2019[50]). Municipalities, which are responsible for development, often lack the resources to provide necessary infrastructure, and they have few incentives to do so since additional tax revenues accrue overwhelmingly to central government. The supply of social housing, provided by municipalities, is very low and often in areas far from job opportunities. 
Figure 16. Housing supply seems not to follow demand

Total dwellings completed in a year as a share of the existing housing stock, \%, 2018 or latest year

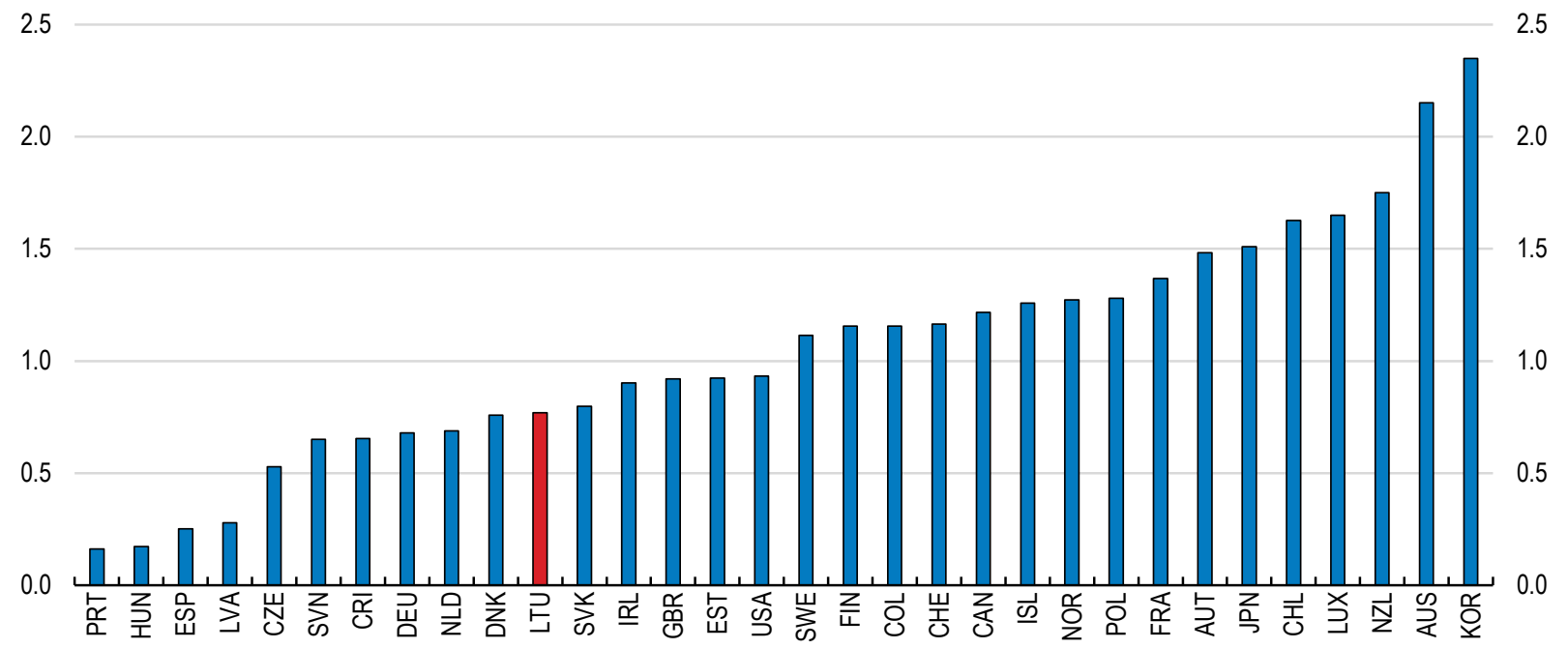

Source: OECD Affordable Housing Database.

StatLink 젶ㄴ https://doi.org/10.1787/888934186049

Low-density urban development could be one of the main reasons for elevated house prices in urban areas and a lack of residential mobility in Lithuania (OECD, 2018[51]). Population density in urban areas - although still high compared to other countries - has considerably decreased over the past two decades, similar to other Central and Eastern European countries, with development mainly taking place at the extensive margin around large conurbations (Figure 17). Low-density development, sometimes following regulation requiring minimum lot size, not only reduces supply in a given area, it also tends to rise property prices, discouraging lower-income households to move towards core areas (Blöchliger et al., 2017 [52]). Moreover, low-density development could be responsible for excessive urban sprawl, especially if zoning regulation sets explicit building limits. Low-density development and urban sprawl are also associated with higher per capita public infrastructure cost, higher energy consumption and higher car use.

Fostering higher-density development and slowing excessive urban sprawl to provide better access to housing is a complex endeavour, requiring reforms in various policy areas. The main lever is to provide incentives for local governments to increase housing supply while to reduce land consumption (Moreno Monroy, A., et al., 2020[53]). The Comprehensive Plan for the Territory of Lithuania foresees the establishment of financial instruments that encourage local planners to increase population density in builtup areas. Mid-2020 the parliament adopted the law on municipal infrastructure, thereby establishing a development fee for municipal infrastructure, similar to existing schemes at the local level in the United States and other countries. This is welcome. Other policy initiatives should include better coordination of planning at the regional level. Regional councils could ensure the coordination of land use planning across municipal borders and between other policy areas, in particular transport, to ensure balanced development and affordable housing. 
Figure 17. Urban sprawl is increasing, pushing up infrastructure cost

Population density in built-up areas, 2015 and evolution 2000-2015

A. Change in average urban population density

$\%, 2000$ to 2015

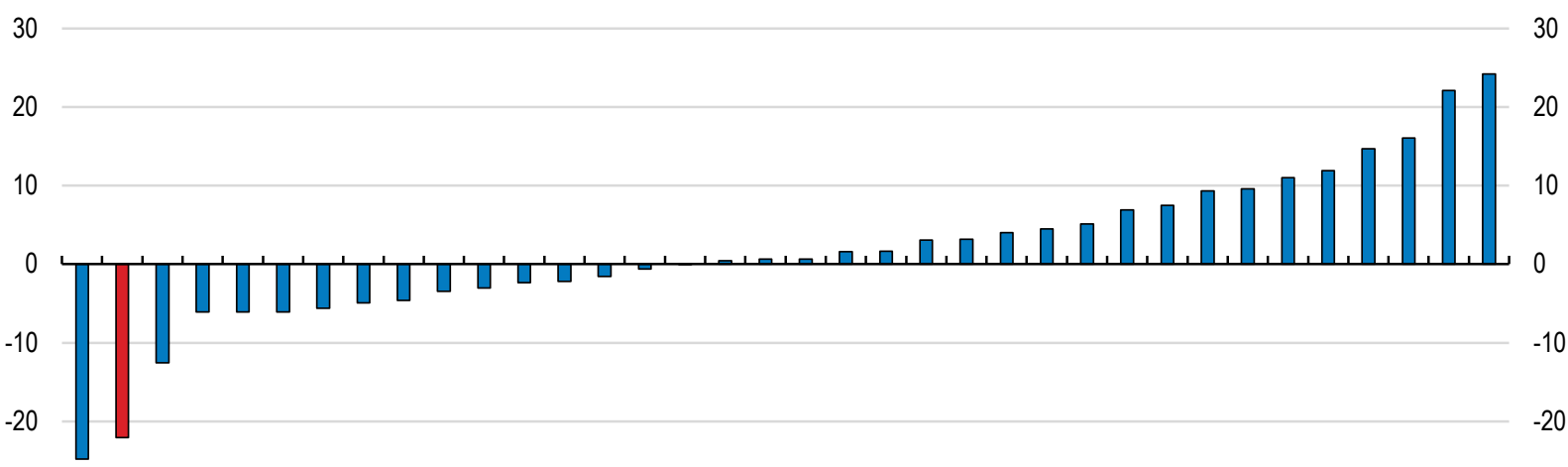

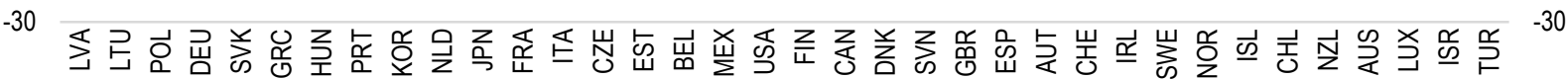

\section{B. Average urban population density}

Thousand inhabitants per $\mathrm{km}^{2}, 2015$

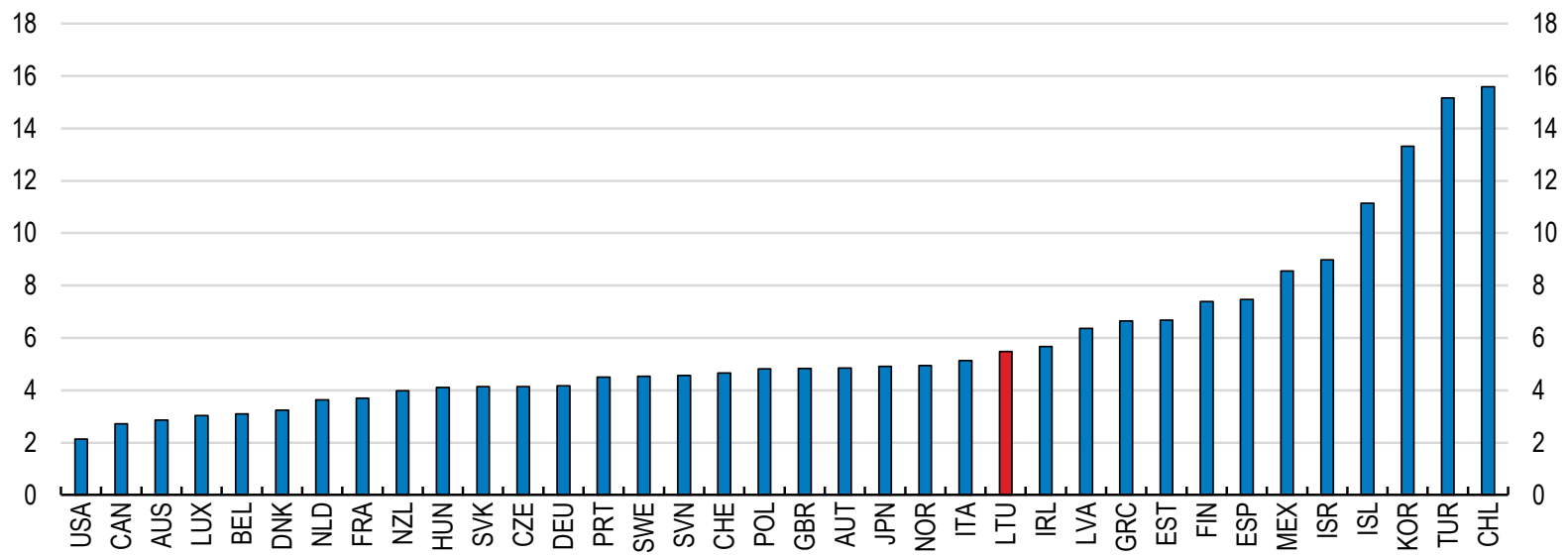

Source: OECD Regional database.

StatLink त्ञाs https://doi.org/10.1787/888934186068

\section{Improving multi-level governance}

Lithuania is highly centralised, leaving sub-national governments little autonomy to develop and implement their own policies (Figure 18). Although relatively large in size on average, the 60 municipalities have few own tax revenues and rely heavily on transfers from the central government to cover spending responsibilities in education, health care and social services. The gap between spending and own revenue is even larger for municipalities outside large conurbations. Following an administrative reform in 2010 , the 10 counties, an intermediate administrative level created in 1995, were abolished. The law on regional development of 2020 introduced a regional level again, by creating regional development councils. A stronger role of the municipalities could raise the local potential for growth, while the newly institutionalised regional level could help address policy coordination across municipalities and the reorganisation of "surplus infrastructure". 
Figure 18. Lithuania is highly centralised

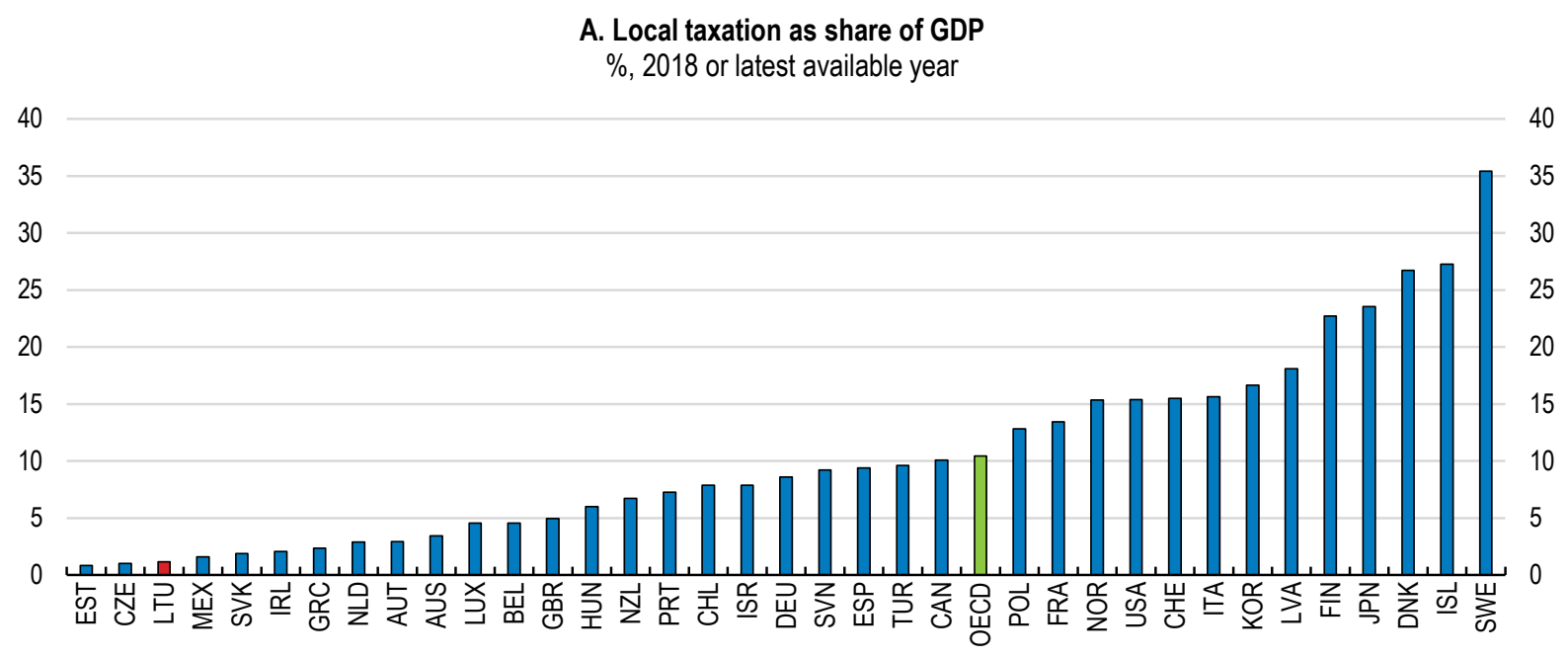

B. Composition of local government revenue $\%$ of total local revenue, 2018 or latest available year

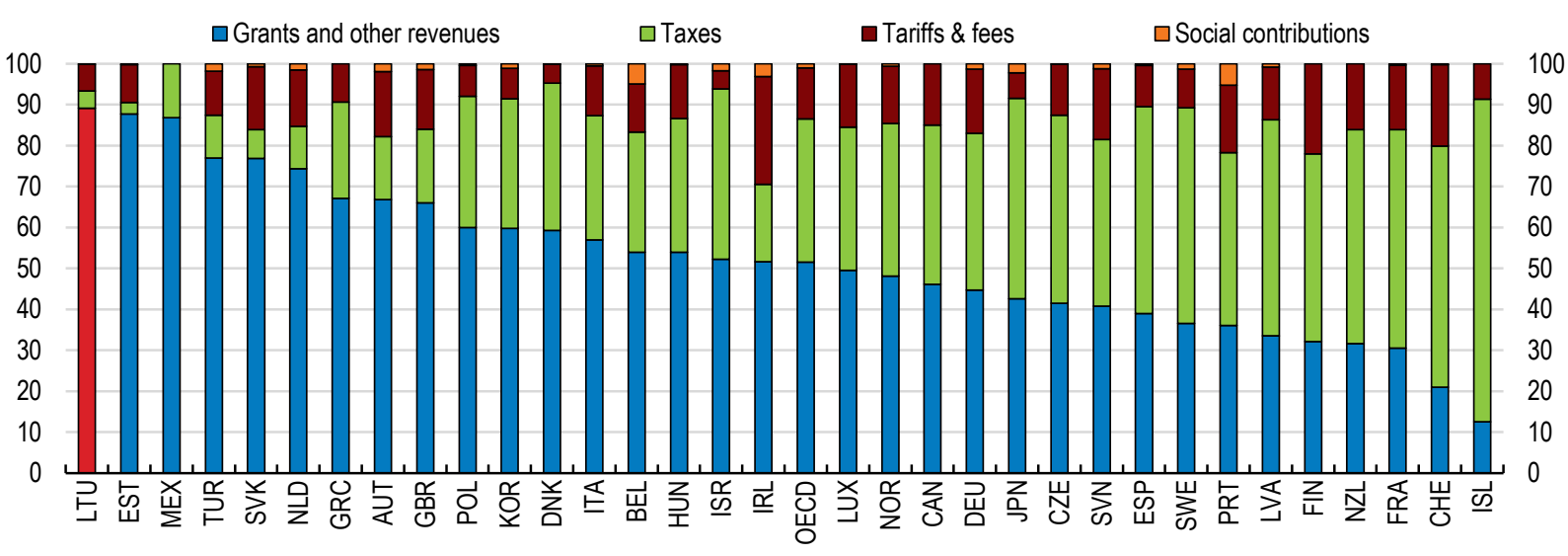

Source: OECD Global Revenue Statistics database; and OECD Government at a Glance database.

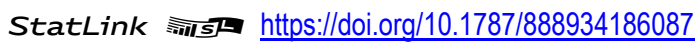

\section{Local investment is low and declining}

Local investment is low and declining, in a context of low overall public investment (Figure 19). Low ownsource revenues and tight local fiscal rules limit willingness and capacity of municipalities to renew or upgrade infrastructure to increase productivity and quality of public services. Municipalities, responsible for land development, have no strong fiscal incentives to attract business investment since they have to assume infrastructure cost while resulting tax revenues accrue mainly to the central government. Central government retains the residential property tax, reducing local fiscal capacity and development incentives further. As a result, many development sites lack sufficient scale to cater to foreign firms that want to set up business in Lithuania.. Overall, a higher share of own-source revenue is associated with higher public, including local, investment (Forman, Dougherty and Blöchliger, 2020[54]). 
Figure 19. Local investment is low and declining

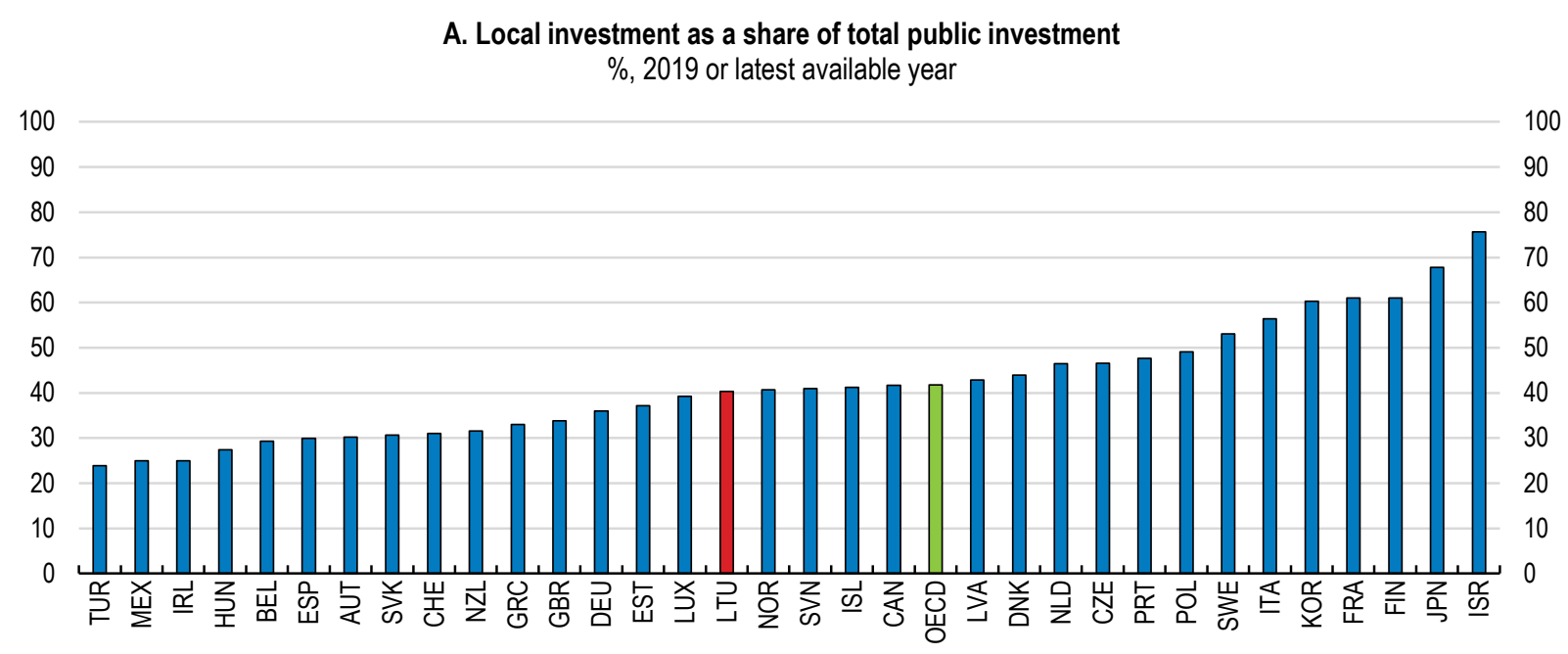

B. Local investment, \% of GDP, change 2002-2018

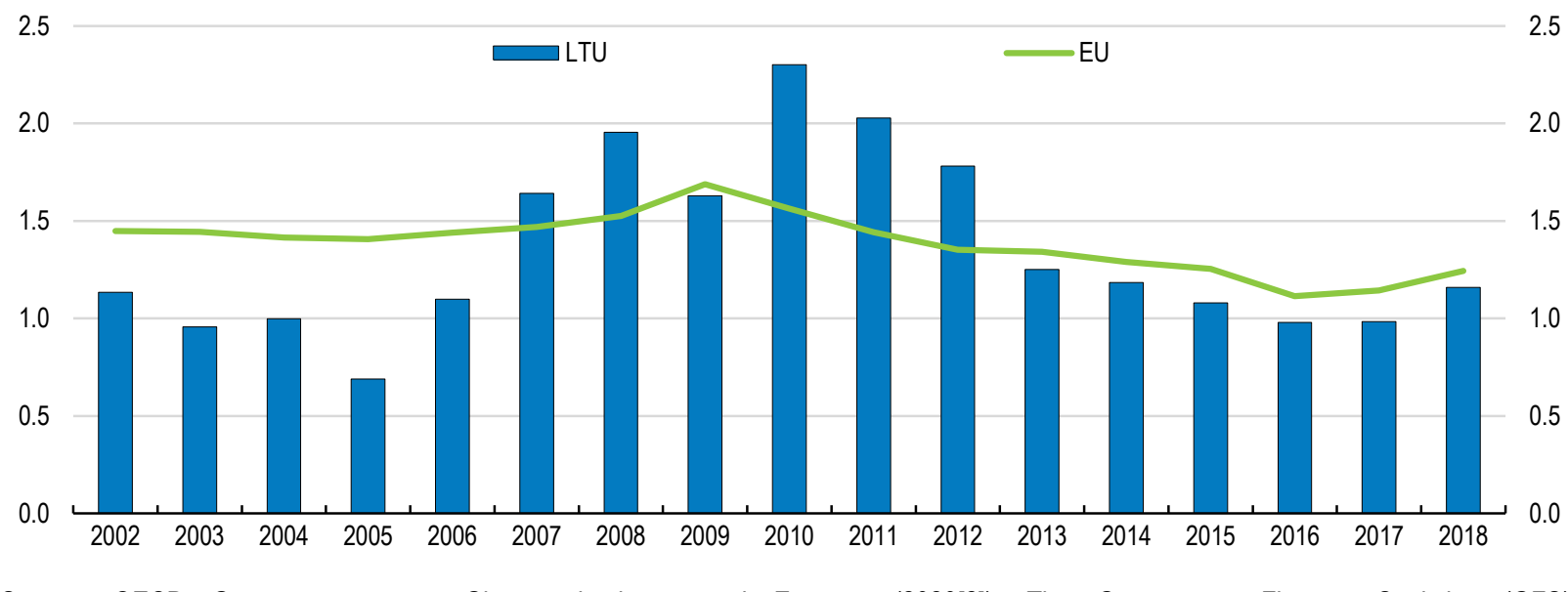

Source: OECD Government at a Glance database; and Eurostat (2020[2]), The Government Finance Statistics (GFS), https://ec.europa.eu/eurostat/web/government-finance-statistics/data.

StatLink :

Over the past few years the government took several initiatives to make the local fiscal framework more investment-friendly. In 2018 it adapted the allocation formula for the personal income tax to better reward municipal efforts to attract residents and payroll and eased the local fiscal rule for some types of investment. Moreover, reforms to the local property tax in 2018 and 2020, namely a lower tax-free threshold for property values, helps fuel property tax revenues, although its share in GDP or total tax revenue remains widely below OECD averages. The government introduced "development fees" charged to the beneficiaries of new developments, akin to models existing in the United States and other countries (Brandt, 2014[55]). There are also plans for local governments to fully retain the central government share in the property tax, similar to plans in the United Kingdom (OECD, 2020 $\left.{ }_{[56]}\right)$. Finally, the government eased regulation and reduced taxation of large-scale investment projects ("green corridor"). To strengthen local willingness and capacity to invest further, the government should continue to increase local own-source revenue, in particular property taxes. 


\section{The planned functional regions will improve investment quality}

A flexible policy coordination across municipalities could help improve level and quality of public investment (Blöchliger and Akgun, 2018 $\left.{ }_{[57]}\right)$. Services like schools, hospitals or transport often require coordination at the supra-local level to reach optimal size and network effects. Moreover, the geographical reach is different for each policy area. Against this background, the establishment of functional regions is a bold step in the right direction. The new regions and their development councils could address the political economy resistance preventing reorganisation of municipal services. As discussed in the previous Survey, regional councils could take over responsibility for the hospital network, for instance. The planned regional administrations should receive adequate decision-making power and funding, and any existing funds discouraging service reorganisation should be abandoned.

Regional councils could also help improve policy coordination in urban areas ("metropolitan governance"). Lithuania counts no bodies covering policymaking and service provision in urban areas, with the exception of Klaipeda, the main port with a supra-municipal body responsible for regional development, land use regulation and cooperation in the Baltic Sea. The counties, initially formed to cover a city or town plus surroundings, have no administrative power. Against this background, productivity in Lithuanian metropolitan areas might be below potential (Ahrend et al., 2014[58]). Improving metropolitan governance along the lines of OECD peer countries could help improve economic performance in metropolitan areas (Box 6). In particular, coordination of urban transport and land use could help reduce infrastructure cost, limit urban sprawl and improve environmental performance. While a metropolitan organisation with an appropriate budget should be set up by local governments, the central government may provide financial support. The new functional regions could act as the springboard for enhanced metropolitan governance.

\section{Box 6. Metropolitan governance: current approaches in OECD countries}

Metropolitan governance varies widely across OECD countries, ranging from lightly organised singlepurpose organisations to fully-fledged government levels covering core policy tasks, mostly as an institutionalised forum for policy makers to strategic planning and coordination of policies across an urban area. More than two-thirds of metropolitan areas, i.e. functional areas with more than 500,000 inhabitants, in OECD countries have some form of institutionalised governance. Organisations dealing with metropolitan areas usually cover a "functional economic area", i.e. commuting zones or the catchment area of a regional labour market. The policy areas these organisations are covering include regional economic development, land use planning, transportation and infrastructure planning and investment. Also, most metropolitan bodies run metro-wide integrated transport systems. In line with a "light" institutional approach, very few metropolitan bodies have their own fiscal power to levy taxes but are funded by contributions from the member municipalities or fees for services.

A number of studies highlight the positive long-term economic and environmental impact of institutionalised metropolitan governance. Where organisations responsible for metropolitan governance exist, metropolitan areas tend to be larger and record lower levels of urban sprawl. Similarly, the existence of metro-wide public transport organisations is correlated with higher levels of public satisfaction and lower levels of air pollution. Growth and productivity are higher in areas with some sort of metropolitan governance body, especially if responsible for transport infrastructure and land use planning. Finally, income inequality seems to be lower in areas with strong metropolitan governance. Given the variety and flexibility of arrangements, governments wishing to achieve better metropolitan governance should aim at these "light" approaches before creating additional intermediate regional government levels.

Source: (Ahrend and Schumann, 2014[59]) (Ahrend, Gamper and Schumann, 2014[60]) (Blöchliger et al., 2017[52]) 


\section{Table 1. Recommendations to foster regional convergence}

\begin{tabular}{l|l}
\hline \multicolumn{2}{c}{ Fostering skills across the country } \\
\hline PISA scores are weak, especially in small rural schools & $\begin{array}{l}\text { Improve educational outcomes by reforming the school network and } \\
\text { by strengthening supervision. }\end{array}$ \\
\hline $\begin{array}{l}\text { Vocational education and training is little developed, } \\
\text { contributing to skills mismatch }\end{array}$ & $\begin{array}{l}\text { Foster and improve vocational education and training, and strengthen } \\
\text { firm-based learning (apprenticeships) }\end{array}$ \\
\hline $\begin{array}{l}\text { The quality of tertiary education is low, and many universities lack } \\
\text { scale }\end{array}$ & $\begin{array}{l}\text { Merge universities, with existing campuses specialising in certain study } \\
\text { fields }\end{array}$ \\
\hline \begin{tabular}{l|l}
\multicolumn{1}{c}{ Investing in sustainable infrastructure } \\
\hline The quality of local and regional transport infrastructure is low
\end{tabular} & $\begin{array}{l}\text { Invest in public transport in urban areas. In rural areas, implement } \\
\text { innovative concepts such as ride-sharing and bundle transport services }\end{array}$ \\
\hline $\begin{array}{l}\text { Transport and its environmental impact is under-priced } \\
\text { Digital infrastructure is thin in rural areas, slowing job creation and } \\
\text { teleworking }\end{array}$ & $\begin{array}{l}\text { Implement mobility-pricing schemes including environmental damage. } \\
\text { neutral regulatory and funding framework for digital providers }\end{array}$ \\
\hline $\begin{array}{l}\text { Imoling up housing and reducing urban sprawl } \\
\text { Housing supply in economically strong areas does not fully keep up }\end{array}$ & $\begin{array}{l}\text { Foster housing through a swift planning and permit system. } \\
\text { with demand, while signs of excessive urban sprawl appear } \\
\text { higher-density development, and improve coordination between transport } \\
\text { and land use planning. }\end{array}$ \\
\hline $\begin{array}{l}\text { The housing rental market is very small, discouraging mobility } \\
\text { Revise rental legislation by clarifying the rights of tenants and } \\
\text { landlords }\end{array}$ \\
\hline $\begin{array}{l}\text { Policy coordination between municipalities is weak, driving } \\
\text { cost and reducing public service quality }\end{array}$ & $\begin{array}{l}\text { Improve coordination of infrastructure and public services across } \\
\text { municipalities }\end{array}$ \\
\hline $\begin{array}{l}\text { Local public investment is low and declining } \\
\text { Increase local own-source revenues, in particular property taxes and } \\
\text { development fees }\end{array}$ \\
\hline
\end{tabular}

Note: Key recommendations are in bold.

\section{References}

Ahrend, R. et al. (2014), "What makes cities more productive? Evidence on the role of urban governance from five countries", OECD Regional Development Working Papers.

Ahrend, R., C. Gamper and A. Schumann (2014), "The OECD Metropolitan Governance Survey: A Quantitative Description of Governance Structures in large Urban Agglomerations", OECD Regional Development Working Papers, No. 2014/4, OECD Publishing, Paris, https://dx.doi.org/10.1787/5iz43zldh08p-en.

Ahrend, R. and A. Schumann (2014), "Approaches to Metropolitan Area Governance: A Country Overview”, OECD Regional Development Working Papers, No. 2014/3, OECD Publishing, Paris, https://dx.doi.org/10.1787/5jz5j1q7s128-en.

Andrews, D. and A. Caldera Sánchez (2011), "Drivers of Homeownership Rates in Selected OECD Countries", OECD Economics Department Working Papers, No. 849, OECD Publishing, Paris, https://dx.doi.org/10.1787/5kgg9mcwc7jf-en.

Bartolini, D., S. Stossberg and H. Blöchliger (2016), "Fiscal Decentralisation and Regional Disparities", OECD Economic Department Working Papers, https://doi.org/10.1787/18151973.

Bhuller, M. et al. (2019), "How Broadband Internet Affects Labour Market Matching", CESifo Working Paper 8022, http://www.cesifo-group.org/wp. 
Binovska, I., L. Kauskale and J. Vanags (2018), "The Comparative Analysis of Real Estate Market Development Tendencies in the Baltic States", Baltic Journal of Real Estate Economics and Construction Management, http://dx.doi.org/doi: 10.1515/bjreecm-2018-0001.

Bisciari, P., D. Essers and E. Vincent (2020), "Does the EU convergence machine still work ?", National Bank of Belgium Economic Review.

Blöchliger, H. and O. Durand-Lasserve (2018), "The drivers of regional growth in Russia: A baseline model with applications", OECD Economics Department Working Papers, No. 1523, OECD Publishing, Paris, https://dx.doi.org/10.1787/9279f6c3-en.

Blöchliger, H. et al. (2017), "Local taxation, land use regulation, and land use: A survey of the evidence", OECD Economics Department Working Papers, No. 1375, OECD Publishing, Paris, https://dx.doi.org/10.1787/52da7c6a-en.

Bonin, I. et al. (2019), "The German Statutory Minimum Wage and its Effect on Regional Employment and Unemployment", Institute of Labour Ecomics Working Paper Policy Paper 145, http://www.iza.org.

Brandt, N. (2014), "Greening the Property Tax", OECD Working Papers on Fiscal Federalism, No. 17, OECD Publishing, Paris, https://dx.doi.org/10.1787/5jz5pzw9mwzn-en.

Causa, O. and J. Pichelmann (forthcoming), "Should I Stay or Should I go? Residential Mobility Across OECD Countries", OECD Economics Department Working Paper.

Cavalleri, M., B. Cournède and E. Özsöğüt (2019), "How responsive are housing markets in the OECD? National level estimates", OECD Economics Department Working Papers, No. 1589, OECD Publishing, Paris, https://dx.doi.org/10.1787/4777e29a-en.

Dotterud, L. and K. Skollerud (2015), Public Transport Services in Norway: Focus on Rural Areas.

Dustmann, D. et al. (2020), "Reallocation Effects of the Minimum Wage", Centre for Research and Analysis of Migration Working Paper 7/20, https://www.creammigration.org/publ uploads/CDP 07 20.pdf.

ESPON (2015), Transport Accessibility at regional/local scale in Europe.

European Bank for Reconstruction and Development (2019), Driving change: reforming urban bus services.

European Commission (2020), Digital Economy and Society Index.

European Commission (2019), Transport in the European Union. Current Trends and Issues.

European Commission (2012), Apprenticeship Supply in the Member States of the European Union.

Eurostat (2019), Distribution of population by tenure status, type of household and income group - EU-SILC survey, https://appsso.eurostat.ec.europa.eu/nui/submitViewTableAction.do (accessed on 17 October 2019).

Forman, K., S. Dougherty and H. Blöchliger (2020), "Synthesising Good Practices in Fiscal Federalism: Key recommendations from 15 years of country surveys", OECD Economic Policy Paper 28. 
Gal, P. et al. (2019), "Digitalisation and productivity: In search of the holy grail - Firm-level empirical evidence from EU countries", OECD Economics Department Working Papers, No. 1533, OECD Publishing, Paris, https://dx.doi.org/10.1787/5080f4b6-en.

Glaeser, E. (2008), Cities, Agglomeration and Spatial Equilibrium, Oxford.

Glaeser, E. and J. Gyourko (2018), "The Economic Implications of Housing Supply", Journal of Economic Perspectives.

Glocker, D. and M. Plouin (2016), "(2016), "Overview of Housing Policy Interventions in Poland",", OECD Regional Development Working Papers, http://dx.doi.org/dx.doi.org/10.1787/5j|p/4n838f2-en.

Gupta, A., S. Van Nieuwerburgh and C. Kontokosta (2020), "Take the Q Train: Value Capture of Public Infrastructure Projects”, NBER Working Paper 26789, http://www.nber.org/papers/w26789.

lacovos, I. (2018), "Housing Price, Credit, and Output Cycles: How Domestic and External Shocks Impact Lithuania's Credit”, IMF Working Paper 18/160.

International Transport Forum (2010), Implementing Congestion Charges, https://www.itfoecd.org/road-pricing-roundtable.

Invest Lithuania (2019), The manufacturing landscape in Lithuania.

Jakimavičius, M. and M. Burinskiene (2007), "Automobile transport system analysis and ranking in Lithuanian administrative regions", Transport, http://dx.doi.org/doi.org/10.1080/16484142.2007.9638127.

Kim, J. (ed.) (2018), Fiscal Decentralisation and Economic Growth, OECD Publishing, http://dx.doi.org/doi.org/10.1787/9789264302488-en.

Lithuanian Free Market Institute (2019), How do municipal undertakings work?.

Ministry of Transport and Communications (2014), National Transport Development Plan 201422.

Moreno Monroy, A., et al. (2020), "Housing policies for sustainable and inclusive cities", OECD Regional Development Working Papers 2020/03, http://dx.doi.org/doi.org/10.1787/d63e9434en.

Moretti, L. et al. (2017), "So Similar and yet so Different: A Comparative Analysis of a Firm's Cost and Benefits of Apprenticeship Training in Austria and Switzerland", IZA Institute of Labor Economics Discussion Paper 11081, http://www.iza.org.

National Audit Office (2019), Granting Construction Permit and Compliance of Construction Process to the Set Requirements, http://www.vkontrole.lt.

National Audit Office (2017), Could Lithuanian Students perform better?, http://www.vkontrole.lt.

National Audit Office (2016), Monitoring of Education, http://www.vkontrole.It.

National Audit Office (2016), Taking Advantage of Vocational Training Possibilities. 
National Regional Development Council (2017), Lithuanian Regional Policy White Paper for Harmonious and Sustainable Development.

OECD (2020), Economic Surveys: United Kingdom, OECD Publishing, Paris.

OECD (2020), Policy Actions for Affordable Housing in Latvia.

OECD (2019), Measuring the Digital Transformation: A Roadmap for the Future, OECD

Publishing, Paris, https://dx.doi.org/10.1787/9789264311992-en.

OECD (2018), "Bridging the rural digital divide", OECD Digital Economy Papers, No. 265, OECD Publishing, Paris, https://dx.doi.org/10.1787/852bd3b9-en.

OECD (2018), Rethinking Urban Sprawl: Moving Towards Sustainable Cities, OECD Publishing, Paris, https://dx.doi.org/10.1787/9789264189881-en.

OECD (2018), Seven Questions about Apprenticeships: Answers from International Experience, OECD Reviews of Vocational Education and Training, OECD Publishing, Paris, https://dx.doi.org/10.1787/9789264306486-en.

OECD (2017), Education in Lithuania, Reviews of National Policies for Education, OECD Publishing, Paris, https://dx.doi.org/10.1787/9789264281486-en.

OECD (2017), OECD Economic Surveys: Latvia 2017, OECD Publishing, Paris, https://dx.doi.org/10.1787/eco surveys-Iva-2017-en.

OECD (2016), Competition and Innovation in Land Transport.

OECD (2014), Skills beyond School: Synthesis Report, OECD Reviews of Vocational Education and Training, OECD Publishing, Paris, https://dx.doi.org/10.1787/9789264214682-en.

OECD/ITF (2019), Tax Revenue Implications of Decarbonising Road Transport: Scenarios for Slovenia, OECD Publishing, Paris, http://dx.doi.org/doi.org/10.1787/87b39a2f-en.

Pociute-Sereikiene, G., E. Kriauciunas and R. Ubareciviene (2014), "Peripheralisation trends in rural territories: the case of Lithuania", Studies in Agricultural Economics 116, pp. 122-130, http://dx.doi.org/dx.doi.org/10.7896/j.1421.

Rusticelli, E. and al (2018), "Going local: a regional perspective on how trade affects labour markets and inequality", OECD Economics Department Working Papers 1530, http://dx.doi.org/doi.org/10.1787/2981f94c-en.

Schwellnus, C. et al. (2018), "Labour share developments over the past two decades: The role of technological progress, globalisation and "winner-takes-most" dynamics", OECD Economics Department Working Papers, No. 1503, OECD Publishing, Paris, https://dx.doi.org/10.1787/3eb9f9ed-en.

Shewbridge, C. et al. (2016), OECD Reviews of School Resources: Lithuania 2016, OECD Reviews of School Resources, OECD Publishing, Paris, https://dx.doi.org/10.1787/9789264252547-en.

Smart, M. (2004), "Equalisation and Stabilisation", Canadian Public Policy, Vol. 30/2, 
34 | ECO/WKP(2020)58

The Guardian (2019), The Innisfil experiment,

https://www.theguardian.com/cities/2019/jul/16/the-innisfil-experiment-the-town-that-replacedpublic-transit-with-uber.

Tsvetkova, A. et al. (2020), "The spatial dimension of productivity: Connecting the dots across industries, firms and places", OECD Regional Development Working Papers, No. 2020/01, OECD Publishing, Paris, https://dx.doi.org/10.1787/ba5edb47-en. 